\title{
Review \\ Therapeutic Potential and Nutraceutical Profiling of North Bornean Seaweeds: A Review
}

\author{
Muhammad Dawood Shah ${ }^{1, *(1)}$, Balu Alagar Venmathi Maran ${ }^{1}\left[{ }^{(}\right)$, Sitti Raehanah Muhamad Shaleh ${ }^{1}$, \\ Wahidatul Husna Zuldin ${ }^{1}$, Charles Gnanaraj ${ }^{2}$ (I) and Yoong Soon Yong ${ }^{3}$ (i)
}

1 Borneo Marine Research Institute, Universiti Malaysia Sabah, Kota Kinabalu 88400, Sabah, Malaysia; bavmaran@ums.edu.my (B.A.V.M.); sittirae@ums.edu.my (S.R.M.S.); wahidatul@ums.edu.my (W.H.Z.)

2 Faculty of Pharmacy and Health Sciences, University Kuala Lumpur Royal College of Medicine Perak, Ipoh 30450, Perak, Malaysia; charles.gnanaraj@unikl.edu.my

3 Laboratory Center, Xiamen University Malaysia, Sepang 43900, Selangor, Malaysia; yoongsoon.yong@xmu.edu.my

* Correspondence: dawoodshah@ums.edu.my

check for updates

Citation: Shah, M.D.; Venmathi Maran, B.A.; Shaleh, S.R.M.; Zuldin, W.H.; Gnanaraj, C.; Yong, Y.S. Therapeutic Potential and Nutraceutical Profiling of North Bornean Seaweeds: A Review. Mar. Drugs 2022, 20, 101. https://doi.org/ $10.3390 / \mathrm{md} 20020101$

Academic Editors: Alberto Falco and Mikolaj Adamek

Received: 22 December 2021

Accepted: 14 January 2022

Published: 25 January 2022

Publisher's Note: MDPI stays neutral with regard to jurisdictional claims in published maps and institutional affiliations.

Copyright: (c) 2022 by the authors. Licensee MDPI, Basel, Switzerland. This article is an open access article distributed under the terms and conditions of the Creative Commons Attribution (CC BY) license (https:// creativecommons.org/licenses/by/ $4.0 /)$.

\begin{abstract}
Malaysia has a long coastline surrounded by various islands, including North Borneo, that provide a suitable environment for the growth of diverse species of seaweeds. Some of the important North Bornean seaweed species are Kappaphycus alvarezii, Eucheuma denticulatum, Halymenia durvillaei (Rhodophyta), Caulerpa lentillifera, Caulerpa racemosa (Chlorophyta), Dictyota dichotoma and Sargassum polycystum (Ochrophyta). This review aims to highlight the therapeutic potential of North Bornean seaweeds and their nutraceutical profiling. North Bornean seaweeds have demonstrated anti-inflammatory, antioxidant, antimicrobial, anticancer, cardiovascular protective, neuroprotective, renal protective and hepatic protective potentials. The protective roles of the seaweeds might be due to the presence of a wide variety of nutraceuticals, including phthalic anhydride, 3,4-ethylenedioxythiophene, 2-pentylthiophene, furoic acid (K. alvarezii), eicosapentaenoic acid, palmitoleic acid, fucoxanthin, $\beta$-carotene (E. denticulatum), eucalyptol, oleic acid, dodecanal, pentadecane (H. durvillaei), canthaxanthin, oleic acid, pentadecanoic acid, eicosane (C. lentillifera), pseudoephedrine, palmitic acid, monocaprin (C. racemosa), dictyohydroperoxide, squalene, fucosterol, saringosterol (D. dichotoma), and lutein, neophytadiene, cholest-4-en-3-one and cis-vaccenic acid (S. polycystum). Extensive studies on the seaweed isolates are highly recommended to understand their bioactivity and mechanisms of action, while highlighting their commercialization potential.
\end{abstract}

Keywords: Borneo seaweeds; marine algae; nutraceuticals; therapeutic potential; anti-inflammatory; antimicrobial; antioxidant

\section{Introduction}

Marine organisms have been widely used as sources of functional bioactive compounds over the years [1]. Among marine resources, seaweeds (multicellular marine algae) are well-documented natural sources of proteins, nitrogen compounds, carbohydrates as well as lipids, vitamins, minerals, pigments and volatile compounds [1,2]. Based on chlorophyll, seaweeds are divided into three groups-green algae (Chlorophyceae), red algae (Rhodophyceae), and brown algae (Phaeophyceae) [3] —and possess a wide range of biological potentials that are beneficial against several disorders such as cytotoxic, antioxidant, anti-inflammatory, and antimitotic activities [4,5]. Due to population growth, fast industrial growth, and the public's desire for natural products, worldwide demand for seaweed products is anticipated to grow even more in the years ahead [6].

Malaysia is part of the Coral Triangle, a geographical area in Southeast Asia and the Pacific that includes the oceans close to Indonesia, Malaysia, Philippines, Papua New Guinea, Timor-Leste and Solomon Islands. The temperatures of Malaysia's coastal waters make it ideal for the development and growth of a wide variety of seaweed species. The 
North Borneo region of Malaysia is one of the main seaweeds growing areas; it has a suitable environment for cultivating a diverse variety of seaweeds and is the only region of Malaysia where seaweeds are farmed commercially [7]. In North Borneo (Sabah state), seaweeds cultivation was introduced in 1978 and the primary seaweeds cultivating sites are Semporna, Kunak, Lahad Datu and Bangi [8]. In 2008, approximately 111,298 tonnes of seaweeds were cultivated; Semporna accounted for $95 \%$, Lahad Datu $4.4 \%$, Bangi $0.3 \%$, and Kunak 0.3\% [7]. Some of the common species of seaweeds found in North Borneo are Kappaphycus alvarezii (Doty) Doty, Eucheuma denticulatum (Burman) Collins et Harvey, Halymenia durvillaei Bory de Saint-Vincent, Caulerpa lentillifera J. Agardh, Caulerpa racemosa (Forsskål) J. Agardh, Dictyota dichotoma (Huds.) Lamouroux, and Sargassum polycystum C. Agardh [9]. Brief descriptions regarding North Bornean seaweeds are listed in Table 1.

Table 1. Descriptions of North Bornean seaweed species.

\begin{tabular}{|c|c|c|c|c|}
\hline Species & Phylum & Family & Other Names & References \\
\hline $\begin{array}{c}\text { Kappaphycus } \\
\text { alvarezii }\end{array}$ & Rhodophyta & Solieriaceae & $\begin{array}{c}\text { Eucheuma cottonii } \\
\text { or sea bird nest }\end{array}$ & [9-11] \\
\hline $\begin{array}{c}\text { Eucheuma } \\
\text { denticulatum }\end{array}$ & Rhodophyta & Solieriaceae & $\begin{array}{l}\text { Eucheuma } \\
\text { spinosum }\end{array}$ & {$[9,10,12]$} \\
\hline $\begin{array}{l}\text { Halymenia } \\
\text { durvillaei }\end{array}$ & Rhodophyta & Halymeniaceae & & {$[9,10]$} \\
\hline $\begin{array}{c}\text { Dictyota } \\
\text { dichotoma }\end{array}$ & Ochrophyta & Dictyotaceae & & {$[9,10]$} \\
\hline $\begin{array}{l}\text { Sargassum } \\
\text { polycystum }\end{array}$ & Ochrophyta & Sargassaceae & & {$[9,10]$} \\
\hline $\begin{array}{l}\text { Caulerpa } \\
\text { lentillifera }\end{array}$ & Chlorophyta & Caulerpaceae & Sea grape & {$[9,10]$} \\
\hline $\begin{array}{l}\text { Caulerpa } \\
\text { racemosa }\end{array}$ & Chlorophyta & Caulerpaceae & Sea grape & {$[9,10]$} \\
\hline
\end{tabular}

\section{Therapeutic Potential of North Bornean Seaweeds}

Seaweeds are also known as sea vegetables and have been used for the treatment of various disorders [13-16]. Anti-inflammatory, antioxidant, antimicrobial, and anticancer properties as well as cardiovascular protection, renal protection, hepatoprotection, and neuroprotection are only a few of the medicinal activities of seaweed that have been previously described $[9,16-22]$. Some of the protective actions of North Bornean seaweeds are discussed below.

\subsection{Anti-Inflammatory Activity}

Inflammation is a recognized defensive mechanism evolved in high-level organisms in response to stressors that disrupt bodily homeostasis. Microbial infections, tissue stress and some traumas are examples of hazards that cause inflammation with common symptoms of fever, redness, swelling and pain $[23,24]$. Overproduction of pro-inflammatory cytokines including tumor necrosis factor-alpha (TNF- $\alpha$ ), interleukin (IL) (IL-6 and IL-1), prostaglandin E2 (PGE2), nitric oxide (NO), and enhanced production of reactive oxygen species (ROS) define the inflammatory response [25]. Increased activity of inducible nitric oxide synthase (iNOS) and cyclooxygenase-2 (COX-2) is associated with increased $\mathrm{NO}$ and PGE2 production [26].

K. alvarezii has been reported to have anti-inflammatory potential in asthma-induced rats. The extract changed circulating white blood cell levels, reduced mucin synthesis, and downregulated the expression of TNF- $\alpha$, IL-4, nuclear factor kappa beta (NF-kB), epidermal growth factor receptor (EGFR) and matrix metalloproteinase (MMP-9). The consumption of seaweed may be useful for asthma patients. The extract decreases bronchiole smooth muscle thickness for airflow facilitation and decreases asthmatic inflammation, lung eosinophil infiltration, and mucin production [16]. 
The anti-inflammatory activity of C. lentillifera polysaccharides has been reported to have an inhibitory impact on lipopolysaccharide (LPS)-induced HT29 colorectal carcinoma cells, lowering the overproduction of TNF- $\alpha$ and IL-1 $\beta$, SIgA and mucin2 (related proteins), as well as decreasing TNF- $\alpha$ and IL-1 $\beta$ expression [27]. C. racemosa polysaccharides have been reported to have anti-inflammatory potential and activate the hemoxigenase- 1 (HO- 1 ) pathway to sustain the production of hemoxigenase-1 enzyme, crucial for the prevention of inflammation [28].

In murine macrophage RAW 264.7 cells, the dichloromethane fraction of $D$. dichotoma extract at a concentration of $25 \mathrm{ug} / \mathrm{mL}$ inhibited the production of $\mathrm{NO}$ and PGE2, followed by a reduction in the expression of inducible nitric oxide synthase (iNOS) and COX-2 proteins, and iNOS and COX-2 mRNA in a dose-dependent pattern. COX-2 and iNOS are implicated in a variety of pathological processes, including inflammation. The solvent fractions of $D$. dichotoma extracts also decrease the mRNA expression of other cytokines including TNF- $\alpha$, IL-1, and IL-6 in the murine macrophage cell line [29].

Anti-inflammatory and analgesic activity from brown algae $S$. polycystum has been reported using a mouse model with the paw edema method, where the mouse paw was inflamed and the hexane fraction of seaweed extract at a concentration of $70 \mathrm{mg} / \mathrm{kg}$ b.w. was applied. The anti-inflammatory effect was measured by the decreased percentage of edema size. The hexane fractions of $S$. polycystum extract significantly reduced the edema size compared to untreated mice [17].

\subsection{Antioxidant Activity}

Antioxidant phytochemical compounds can scavenge the reactive oxygen species (ROS) and reactive nitrogen species (RNS) in the human body, and slow down or prevent the onset of oxidative stress-related diseases including cardiovascular diseases (CVDs), neurological diseases (for example, Alzheimer's disease (AD), Parkinson's disease, multiple sclerosis, amyotrophic lateral sclerosis (ALS), and depression), cancer (chromosomal abnormalities, DNA damage), respiratory disease (chronic obstructive pulmonary disease (COPD) and asthma), rheumatoid arthritis, delayed sexual maturation, and kidney and liver diseases [30-33].

Marine seaweeds from North Borneo are a good source of antioxidants $[9,11,34,35]$. In a study, the antioxidant potential of marine seaweeds from North Borneo was evaluated by the Trolox equivalent antioxidant capacity (TEAC) and ferric reducing antioxidant power (FRAP) methods and total phenolic content by the Folin-Ciocalteu method expressed as phloroglucinol equivalents (PGE) [9]. The antioxidation activities of the North Bornean seaweeds showed good radical-scavenging and reducing power potential. The radicalscavenging and reducing power activities of the seaweeds have been reported in K. alvarezii 1.63 and 225.00 TEAC and FRAP mM.mg/dry extract and 22.50 TPC mg PGE/g dry extract, E. denticulatum 1.54 and 153.97 TEAC and FRAP mM.mg/dry extract and $15.82 \mathrm{TP} \mathrm{mg}$ PGE/g dry extract, $H$. durvillaei 1.67 and 182.29 TEAC and FRAP mM.mg/dry extract and 18.90 TP mg PGE/g dry extract, C. lentillifera 2.16 and 362.11 TEAC and FRAP mM.mg/dry extract and 42.85 TP mg PGE/g dry extract, C. racemosa 2.01 and 355.36 TEAC and FRAP mM.mg/dry extract and 40.36 TP mg PGE/g dry extract, D. dichotoma 1.66 and 268.86 TEAC and FRAP mM.mg/dry extract and 35.23 TP mg PGE/g dry extract, S. polycystum 1.86 and 366.69 TEAC and FRAP mM.mg/dry extract and 45.16 TP mg PGE/g dry extract compared to butylated hydroxytoluene (standard) (3.84 and 615.71 TEAC and FRAP mM.mg/dry extract) [9]. Among the above-mentioned seaweeds, C. lentillifera has high antioxidation activities followed by C. racemosa, S. polycystum, H. durvillaei, D. dichotoma, K. alvarezii and E. denticulatum; while in terms of TP, S. polycystum has indicated high values followed by $C$. lentillifera, C. racemosa, D. dichotoma, K. alvarezii, H. durvillaei and E. denticulatum [9]. 


\subsection{Antimicrobial Activity}

Pathogenic microbes including bacteria, fungi, viruses and parasites are responsible for the development of various diseases that arise in the community [36]. Seaweeds with various bioactive secondary metabolites act as antimicrobial agents [37,38].

The antibacterial potential of the aqueous extraction of K. alvarezii against Staphylococcus aureus (S. aureus) (Rosenbach, 1884) has been examined. Administration of the extract at a concentration of $200 \mathrm{mg} / \mathrm{mL}$ resulted in an inhibition zone of $10.03 \mathrm{~mm}$ [37]. The ethanol extract of K. alvarezii was also effective against S. aureus, Staphylococcus epidermidis (S. epidermidis) (Winslow \& Winslow, 1908), Pseudomonas aeruginosa (P. aeruginosa) (Schroeter, 1872) and Bacillus subtilis (B. subtilis) (Ehrenberg, 1835) bacterial strain at a concentration of $30-80 \%(w / v)$ with an inhibition zone of $11.93-14.85 \mathrm{~mm}$, while ethyl acetate fractions of the ethanol extract of $K$. alvarezii at a concentration of $50 \%(w / v)$ inhibited the growth of $S$. aureus, S. epidermidis, P. aeruginosa and B. subtilis with inhibition zones of 7.14, 19.70, 0.73 and $18.30 \mathrm{~mm}$, respectively. No antifungal activity of K. alvarezii extract and fractions have been published against Candida albicans (C. albicans) (C.P. Robin) Berkhout and Aspergillus niger (A. niger) (Tiegh) [38]. On the other hand, fungicidal activities of $K$. alvarezii extract have been reported against Lagenidium spp and Haliphthoros fungal strains [18]. In Malaysia and Indonesia, Lagenidium thermophilum (L. thermophilum) (K. Nakam., Miho Nakam., Hatai \& Zafran) and Haliphthoros sabahensis (H. sabahensis) (Y. N. Lee, K. Hatai, O. Kurata, 2017) are pathogenic to the eggs and larval stages of Scylla serrata (Forskål, 1775) and Scylla tranquebarica (Fabricius, 1798) (mangrove crabs) [39,40]. The ethanol extract of K. alvarezii inhibited the hyphal growths of L. thermophilum IPMB 1401 (Y. N. Lee, K. Hatai, O. Kurata, 2016) and H. sabahensis IPMB 1402 [18]. Regarding antiviral activity, it has been reported that red algal lectin ECA-2 obtained from K. alvarezii (currently known as KAA-2 of K. alvarezii) exhibited strong anti-influenza activity against a wide spectrum of influenza virus strains, including the newly evolving swine-origin H1N1-2009 influenza strain. The mechanism involved the direct binding of ECA-2 to the viral envelope protein hemagglutinin (HA) and inhibited influenza virus propagation [41].

The ethanol extract of E. denticulatum inhibited the growth of S. aureus with inhibition zones of $6.0-16.3 \mathrm{~mm}$. Furthermore, the minimum inhibitory concentration (MIC) and minimum bactericidal concentration (MBC) values for E. denticulatum extract against $S$. aureus were $10 \%$ and $15 \%$, respectively. At $10 \%$, minimum bacterial growth was observed, the number of bacteria greatly decreased from $3.0 \times 10^{7}$ to $1.5 \times 10^{2} \mathrm{CFU} /$ plate, and turbidity levels also decreased; while at $15 \%$ of the extract, no bacterial growth was noticed [42]. No antifungal activity of $E$. denticulatum extract has been reported against Aspergillus flavus ( $A$. flavus) (Link) [43]. Sulphated polydigalactosides (carrageenans) extracted from E. denticulatum have been tested for in vitro antiviral activity against human herpes virus type 1 (HHV-1). Carrageenans indicated an antiviral impact by the inhibition of virus attachment and interference in a subsequent stage of the virus replicative cycle. HHV-1 viral DNA synthesis was reduced by 3 folds in cultures treated with sulphated polydigalactosides from E. denticulatum $(0.75 \mathrm{mg} / \mathrm{mL})$ [44].

The extracts of $H$. durvillaei has been reported to have antimicrobial effects. The presence of antimicrobial activities of $H$. durvillaei extract against pathogenic bacteria was determined using the disc diffusion method. The solvent extract of $H$. durvillaei inhibited the growth of P. aeruginosa $(11.89 \mathrm{~mm})$, S. aureus $(12.22 \mathrm{~mm})$, and Streptococcus pyogenes (S. pyogenes) Rosenbach, $1884(10.67 \mathrm{~mm})$, respectively. However, no fungicidal activity of the solvent extract of $H$. durvillaei has been reported against $C$. albicans [45].

The chloroform extracts of $C$. lentillifera were tested against Methicillin-resistant $S$. aureus (MRSA) and neuropathogenic Escherichia coli K1 (E. coli K1). Moderate antibacterial activity of $62.17 \%$ against MRSA and poor antibacterial impact against $E$. coli $\mathrm{K} 1$ of $12.42 \%$ were demonstrated by C. lentillifera extract at a concentration of $250 \mu \mathrm{g} / \mathrm{mL}$ [35]. However, no antibacterial effect from an aqueous extract of $C$. lentillifera $(0-128 \mu \mathrm{g} / \mathrm{mL})$ was recorded against the shrimp pathogenic bacteria Vibrio vulnificus (Reichelt et al., 1979) Farmer, 1980, V. alginolyticus (Miyamoto et al., 1961) Sakazaki, 1968, V. parahaemolyticus (Fujino et al., 
1951) Sakazaki et al., 1963 or V. harveyi, (Kornicker \& King, 1965), as compared with positive (enrofloxacin, $128 \mu \mathrm{g} / \mathrm{mL}$ ) and negative controls [46]. The antiviral activity of $C$. lentillifera extract was tested against White Spot Syndrome Virus (WSSV) (family Nimaviridae, consisting of a large circular double-stranded DNA genome) [46,47]. WSSV infects shrimps and is characterized by the presence of circular white patches in the cuticle of the cephalothorax and abdominal segments, with a reddish to pinkish color. In Asia and Americas, WSSV caused mass mortalities (80-100\%) of cultured shrimps [48]. The administration of $C$. lentillifera extract yielded very good outcomes. Shrimps injected with WSSV and C. lentillifera $(1-10 \mathrm{mg} / \mathrm{mL})$ preincubated solutions exhibited significantly lower mortality of $0.0-6.7 \%$, compared with the positive control (100\%) (only WSSV-injected). This inhibitory effect was further confirmed by the reduction in viral loads of WSSV, and C. lentillifera $(1-10 \mathrm{mg} / \mathrm{mL})$ expressed significantly lower viral loads $\left(0.00-0.79 \log _{10}\right.$ copies number $/ \mu \mathrm{g}$ of total DNA, respectively) than the positive control (4.39 $\log _{10}$ copies number/ $\mu \mathrm{g}$ of total DNA) [46]. Fungicidal activities of C. lentillifera against $L$. thermophilum and $H$. sabahensis have been reported as well. An ethanol extract of $C$. lentillifera inhibited hyphal growths of L. thermophilum IPMB 1401, L. thermophilum IPMB 1601 and H. sabahensis IPMB 1603 [18].

A chloroform extract of $C$. racemosa demonstrated antibacterial activity against MRSA and E. coli K1. The extract of $C$. racemosa, at a concentration of $250 \mu \mathrm{g} / \mathrm{mL}$, displayed a high antibacterial effect of $97.7 \%$ against MRSA, but a weak effect of $19.90 \%$ against $E$. coli $\mathrm{K} 1$. A methanol extract of C. racemosa $(250 \mu \mathrm{g} / \mathrm{mL})$ also showed antibacterial activity of $61.54 \%$ and $42.91 \%$ against MRSA and E. coli K1 [35], respectively. C. racemosa has been reported to show antifungal activity against $A$. flavus. An ethanol extract of the seaweed demonstrated the strongest inhibitory power with a $30 \mathrm{~mm}$ diameter inhibition zone against A. flavus [43]. The antiviral activity of a solvent extract of C. racemosa was demonstrated against the Chikungunya virus (CHIKV) [49]. The virus belongs to the alphavirus genus of the Togaviridae family, an RNA virus mostly spread by bites of Aedes aegypti and Aedes albopictus mosquitoes, which cause high fever, joint pain, back pain, vomiting, headache, kidney, liver, heart disease, etc. [50]. The antiviral potential of a solvent extract of $C$. racemosa was determined based on inhibition of the cytopathic effect caused by CHIKV on African monkey kidney epithelial (Vero) cells. Chloroform, ethyl acetate, ethanol, and methanol extracts (5 to $640 \mu \mathrm{g} / \mathrm{mL}$ ) of C. racemosa showed a significant inhibition effect [49].

Methanol, dichloromethane and hexane extracts of $D$. dichotoma at a concentration of $1.5 \mathrm{mg} /$ disc were investigated for in vitro antibacterial and antifungal activities. The results indicated that the methanol extract inhibited the growth of B. subtilis $(6.5 \mathrm{~mm})$ and $S$. aureus $(7.5 \mathrm{~mm})$. The dichloromethane extract inhibited the growth of B. subtilis $(7.0 \mathrm{~mm})$, Enterobacter aerogenes (E. aerogenes) (Hormaeche \& Edwards, 1960) $(6.5 \mathrm{~mm})$, E. coli $(6.5 \mathrm{~mm})$, Proteus vulgaris (P. vulgaris) $(11.0 \mathrm{~mm})$ and Salmonella typhimurium (S. typhimurium) (Loeffler, 1892) $(7.0 \mathrm{~mm})$, whereas the hexane extract inhibited the growth of B. subtilis $(9.0 \mathrm{~mm})$ and S. aureus $(7.5 \mathrm{~mm})$ only [51]. The antibacterial activity of the ethanol extract of $D$. dichotoma has been shown against Salmonella typhi (S. typhi), Klebsiella pneumoniae (K. pneumoniae) (Schroeter, 1886) Trevisan, 1887 and Shigella boydii (S. boydii) (Ewing, 1949) [52]. The antifungal activity of diethyl ether, methanol, and acetone extracts of D. dichotoma has been reported against Mucor sp. and A. flavus [52], while no antifungal activity of the solvent extracts of $D$. dichotoma $(1.5 \mathrm{mg} /$ disc $)$ has been observed against C. albicans [51]. The antiviral activity of various fractions of D. dichotoma extract has been tested against herpes simplex virus (HSV) and coxsackievirus B3 (CVB3) [53]. HSV belongs to the Herpesviridae Family, has a double-stranded DNA structure, infects humans, and causes a variety of illnesses ranging from mild mucocutaneous infections to life-threatening infections, whereas CVB3 belongs to the Picornaviridae Family, has a single-stranded RNA structure, and is responsible for a wide spectrum of human diseases, from asymptomatic to deadly infections $[54,55]$. The antiviral properties of the fractions were recorded in terms of virus plaque inhibition on a Vero cell monolayer. The fractions indicated moderated antiviral activities against both HSV and CVB3 viruses [53]. 
A solvent extract of $S$. polycystum was tested against human pathogenic bacteria. The methanol extract of the seaweed resulted in the inhibition of P. aeruginosa $(15 \mathrm{~mm}), K$. pneumoniae $(16 \mathrm{~mm})$, E. coli $(19 \mathrm{~mm})$, and S. aureus $(20 \mathrm{~mm})$ [56]. However, methanol and ethanol extracts of $S$. polycystum indicated no inhibition against B. subtilis or $S$. enteritidis. Similarly, no antifungal activity has been observed against $A$. niger [57].

\subsection{Anticancer Activity}

Cancer is one of the main causes of mortality in the world, and many research facilities are now focusing on the development of new anticancer medicines that could improve chemotherapy treatment and reduce mortality rates [58]. The protective role of marine products, and especially seaweeds found in North Borneo, in controlling chronic diseases such as cancer has been articulated [19,59-62].

A solvent extract of $K$. alvarezii has been reported with anti-breast and anti-colorectal cancer potential. The anticancer activities were expressed with inhibitory concentration $\left(\mathrm{IC}_{50}\right)$ value $(\mu \mathrm{g} / \mathrm{mL})$. An $\mathrm{IC}_{50}$ value of less than 100 is considered to indicate an active compound with anticancer properties. An ethanolic extract of K. alvarezii exhibited anticancer activity against human breast adenocarcinoma cell line MCF-7 with an $\mathrm{IC}_{50}$ of $75.7 \mu \mathrm{g} / \mathrm{mL}$, while ethyl acetate and hexane extracts showed anti-colorectal cancer activity against human colorectal carcinoma cell line HCT-116 with $\mathrm{IC}_{50}$ values of 21.4 and $43.0 \mu \mathrm{g} / \mathrm{mL}$, respectively [63].

The antitumor activity of E. denticulatum against Ehrlich carcinoma and Meth-A fibrosarcoma has been reported. Oral administration of the extract (1600 mg/kg b.w.) for 28 days resulted in the inhibition of Ehrlich carcinoma by $25 \%$ in tumor-implanted mice. Similarly, intraperitoneal administration of E. denticulatum extract (50 mg/ $\mathrm{kg} \mathrm{b.w.)} \mathrm{for}$ 7 days resulted in the inhibition of Meth-A fibrosarcoma by 17\% [19]. The anticancer activity of crude extracts of $H$. durvelaei was investigated against four cancer cell lines (A549, HT-29, PC-3, and AGS). The results indicated that administration of $H$. durvelaei extracts reduced the growth of AGS and HT-29 cell lines by $27.17 \%$ and $1.47 \%$, respectively [61].

Oligosaccharides ( $\beta-1,3-x y l o o l i g o s a c c h a r i d e s)$ obtained from $C$. lentillifera have been reported to show antitumor properties against human breast adenocarcinoma cell line MCF-7. Exposure to C. lentillifera oligosaccharides inhibited the growth of MCF-7 cells in a dose-dependent manner and induced apoptosis (triggered chromatin condensation and poly ADP-ribose polymerase degradation) [59].

Polysaccharide fractions (coded as CRP) obtained from C. racemosa have been reported to show antitumor activity in tumor-inoculated mice (H22 tumor). The results indicated that administration of $C$. racemosa polysaccharide fractions of different doses could significantly inhibit the $\mathrm{H} 22$ tumor. After 14 days of transplantation, the weight of tumors in mice without polysaccharide treatment increased to $1.02 \mathrm{~g}$ while the tumor weight in mice exposed to the polysaccharide at a dose of $100 \mathrm{mg} / \mathrm{kg}$ b.w./day by routine oral passage decreased to $0.47 \mathrm{~g}$, and the tumor inhibition rate reached $53.9 \%$ [60].

A methanol extract and fractions (petroleum ether, chloroform, ethyl acetate, n-butanol, and aqueous) of $D$. dichotoma were tested against seven different cancer cell lines including HCT-116, MCF-7, HepG2, A-549, PC-3, HeLa, and CACO in 96-well plates. The extract and fractions were applied at concentrations ranging from 0.86 to $100 \mu \mathrm{g} / \mathrm{mL}$. The results demonstrated that $D$. dichotoma extract and fractions displayed significant anticancer effects against several cancer cell lines in a dose-dependent manner but were generally more selective against MCF-7 and PC-3 cell lines. The chloroform fraction was the most effective in MCF-7, PC3, and CACO cells $\left(\mathrm{IC}_{50}=1.93 \pm 0.25,2.20 \pm 0.18\right.$, and $2.71 \pm 0.53 \mu \mathrm{g} / \mathrm{mL}$, respectively) followed by the petroleum ether fraction against MCF-7 and PC-3 $\left(\mathrm{IC}_{50}=4.77 \pm 0.51\right.$ and $3.93 \pm 0.51 \mu \mathrm{g} / \mathrm{mL}$, respectively) and the ethyl acetate fraction against HepG2 and $\mathrm{CACO}\left(\mathrm{IC}_{50}=5.06 \pm 0.21\right.$ and $5.06 \pm 0.23 \mu \mathrm{g} / \mathrm{mL}$, respectively) [62]

The anticancer activity of sulphated polysaccharides (fucoidan) from S. polycystum at a concentration ranging from $25-150 \mu \mathrm{g} / \mathrm{mL}$ has been reported against human breast adenocarcinoma cell line MCF-7 via cell viability assay. Treatment with the sulphated 
polysaccharides indicated the highest percentage of inhibition (90.4\%) against the MCF-7 cell line at $150 \mu \mathrm{g} / \mathrm{mL}$ with an estimated $\mathrm{IC}_{50}$ of $50 \mu \mathrm{g} / \mathrm{mL}$ [64]. In another study, aside from MCF-7 cells, treatment with $S$. polycystum polysaccharide induced apoptosis in colorectal cancer cell lines (HCT-15 cell) [34].

\subsection{Anti-Obesity and Cardiovascular Protection}

The hypocholesterolemic effects of various marine algae and algal polysaccharides have been reported. The administration of extract significantly reduced serum total cholesterol (TC), low-density lipoprotein cholesterol (LDL-C) and triglycerides (TG) [12,20].

After 16 weeks on high-cholesterol/high-fat (HCF) diets, male Sprague-Dawley rats weighing 260-300 g had significantly higher body weight (b.w.), lipid peroxidation (malondialdehyde (MDA), end-product of lipid peroxidation), plasma low-density lipoprotein cholesterol (LDL-C), plasma total cholesterol (TC), plasma triglycerides (TG), erythrocyte glutathione peroxidase (GSH-Px), superoxide dismutase (SOD) and catalase (CAT) levels. The addition of $5 \% \mathrm{~K}$. alvarezii to the HCF diet dramatically decreased body weight (29.1\%), LDL-C (49.3\%), plasma TC (11.4\%), TG (36.1\%), plasma MDA level (10.7\%), GSHPx (13.49\%), SOD (9.4\%) and CAT (24.48\%), and significantly increased HDL-C levels (55\%), compared to rats fed the HCF diet only [20].

E. denticulatum played a vital role in the reduction of fat absorption by the body via inhibition of pancreatic lipase [12]. Inhibiting the absorption of dietary fat is one of the most efficient methods to manage obesity and cardiovascular risks [65,66]. An E. denticulatum extract at a concentration of $3.8 \mathrm{mg} / \mathrm{mL}$ showed pancreatic lipase activity inhibition with an $83 \%$ reduction [12].

Treatment of HCF diet rats with C. lentillifera was reported to show anti-obesity and cardiovascular protection activity. Supplementation with $5 \%$ C. lentillifera extract for 16 weeks in HCF-diet rats reduced body weight by $39.5 \%$, significantly increased HDL-C levels by $48.7 \%$, reduced plasma TC by $18.4 \%$, LDL-C by $34.6 \%$ and TG by $33.7 \%$, and lowered plasma MDA level by $9 \%$, GSH-Px by $31.8 \%$ and CAT by $3.14 \%$, compared to the corresponding levels in high-cholesterol-diet rats [20].

The exposure of induced-hypercholesterolemia and -hypertriglyceridemia rats to S. polycystum significantly reduced body weight gain, plasma antioxidant enzymes and plasma lipid peroxidation to levels closer to those of healthy rats. Supplementation with $5 \%$ S. polycystum in rats fed a high-fat diet reduced body weight by $42.6 \%$, significantly increased HDL-C levels by $16.2 \%$, reduced plasma TC by $11.4 \%$, LDL-C by $22 \%$ and TG by $7.69 \%$, and decreased the plasma MDA level by $6.8 \%$, GSH-Px by $43.4 \%$ and CAT by $15.7 \%$, as compared to the corresponding levels in hypercholesterolemia and hypertriglyceridemia rats [20].

\subsection{Hepatoprotection}

Millions of people die each year as a result of hepatic diseases across the world $[67,68]$. The spread of hepatic disorders is aided by alcohol intake, obesity, nonalcoholic fatty liver disease, viral infection and medications [69-73]. Oxidative stress is one of the mechanisms underlying hepatotoxicity, which occurs when there is an imbalance between the production of reactive oxygen species (ROS) and the antioxidants' ability to scavenge them in the liver [74]. Overproduction of ROS results in the elevation of serum hepatic marker enzymes including serum glutamate pyruvate transaminase (SGPT) or alanine aminotransferase (ALT), serum glutamic-oxaloacetic transaminase (SGOT) or aspartate transaminase (AST), and alkaline phosphatase (ALP), an indication of liver damage. It also induces lipid peroxidation and alters levels of antioxidant enzymes including glutathione peroxidases (GPs), catalase (CAT), superoxide dismutase (SOD), glutathione S-transferase (GST), quinone reductase (QR), etc. [75-77].

The hepatoprotective activity of K. alvarezii ethanolic extract administered for 25 days against lead acetate-induced hepatic injury in mice has been investigated. The extract at a concentration of $800 \mathrm{mg} / \mathrm{kg}$ b.w. reduced AST, ALT and ALP levels by $15.79 \%, 18.52 \%$ 
and $16.11 \%$, respectively, compared to lead acetate-treated mice $(20 \mathrm{mg} / \mathrm{kg}$ b.w. orally once a day for 21 days). Mice administered with ethanol extract of $K$. alvarezii ( $800 \mathrm{mg} / \mathrm{kg}$ b.w.) also demonstrated a significant $(p<0.05)$ elevation in SOD and GPx levels by $45.94 \%$ and $18.78 \%$, respectively, and a significant $(p<0.05)$ reduction in MDA level by $22.83 \%$, compared with lead acetate-treated mice. Histological observations of mouse hepatic tissues treated with $K$. alvarezii ethanolic extract indicated improved hepatic cell structure, blood congestion, and fatty degeneration compared to lead acetate-treated mice [76].

A methanol extract of $C$. lentillifera demonstrated hepatoprotection against acetaminophen (n-acetyl-p-aminophenol; APAP) induced hepatic damage in juvenile zebrafish (aged 1-3 months). The administration of APAP to the control group at a concentration of $10 \mu \mathrm{M}$ caused fish mortality; while the introduction of the methanol extract of $C$. lentillifera at concentrations of 10,20 and $30 \mu \mathrm{g} / 1$ to tanks holding $10 \mu \mathrm{M}$ APAP-treated groups reduced fish mortality. Histological observation by hematoxylin and eosin staining of zebrafish hepatic tissues exposed to $10 \mu \mathrm{M}$ APAP and concurrently administered C. lentillifera extract indicated a reduction in hepatic necrosis, hepatocyte swelling, hepatocyte vacuolization and leukocyte infiltration in a dose-dependent manner, as compared to the control group treated solely with $10 \mu \mathrm{M}$ APAP [78].

An aqueous extract of C. racemosa at a concentration of $200 \mathrm{mg} / \mathrm{kg}$ b.w. was administered for 30 days on a daily basis to $40 \%$ carbon tetrachloride $\left(\mathrm{CCl}_{4}\right)$ induced hepatic fibrosis rats (for 30 days, rats were given $2 \mathrm{~mL} / \mathrm{kg}$ b.w. of $\mathrm{CCl}_{4}$ intraperitoneally on alternate days). Intoxicated rats treated with water extracts of C. racemosa showed significant $(p<0.05)$ decreases in their high levels of AST (46.7\%), ALT (82.2\%), ALP (41.3\%), LDH (25.8\%) and total bilirubin $(69.6 \%)$, as compared to $\mathrm{CCl}_{4}$ treated control rats [79].

The protective effect of a solvent extract of S. polycystum was examined in acetaminophen (single dose administered intraperitoneally, $800 \mathrm{mg} / \mathrm{kg}$ b.w.) induced hepatic oxidative injured rats. The oral administration of $S$. polycystum extract in intoxicated rats at a concentration of $200 \mathrm{mg} / \mathrm{kg}$ b.w./day for 15 days reduced elevated levels of ALT (27.64\%), AST (56.43\%), LDH (43.38\%), ALP (72.53\%) and MDA (31.50\%), compared to the levels in an APAP-administered control group [22].

\subsection{Neuroprotection}

Neuroprotection is a strategy for halting the progression of neurodegeneration [80]. Neurodegeneration is a multifaceted, complicated process that results in the death and loss of neuronal structures in the nervous system. Oxidative stress, calcium dysregulation, axonal transport deficiencies, mitochondrial dysfunction, inappropriate neuron-glial interactions, DNA damage and neuroinflammation are all underlying processes in neurodegeneration [80]. Seaweeds from North Borneo are rich in sulphated and non-sulphated polysaccharides and have been reported to have neuroprotection potential [21,81,82].

It was reported that an extract of $K$. alvarezii might be beneficial as a food supplement or medication for those who are prone to neurological disorders. In primary cultures of hippocampal neurons, the effects of K. alvarezii extracts on the development and complexity of neuronal cytoarchitecture were reported. A solvent extract of $K$. alvarezii with an optimal concentration of $1 \mu \mathrm{g} / \mathrm{mL}$ was added to primary cultures of fetal rat hippocampal neurons. The extract significantly elevated axonal length, number of secondary axonal collateral branches, length of primary dendrites and number of secondary dendritic branches by $58 \%$, 8 folds, $68 \%$ and 2.6 folds, respectively, as compared to control [81].

Alzheimer's disease is a common neurologic disorder, responsible for brain shrinkage and cell death. It is the most prevalent type of dementia and one of the top four causes of mortality in developed countries [83]. So far, the primary symptomatic therapy for this condition has been based on the "cholinergic hypothesis," where the medications increase the level of acetylcholine in the brain by inhibiting the activity of the cholinesterase (acetylcholinesterase and butyrylcholinesterase) enzyme [84]. The anti-butyrylcholinesterase activity of a solvent extract of $D$. dichotoma has been reported. A methanol extract of $D$. dichotoma at a concentration of $1.3-6.5 \mathrm{mg} / \mathrm{mL}$ showed significant $(p<0.05)$ inhibition of 
cholinesterase enzyme (54.42\%), compared to standard donepezil (cholinesterase inhibitor) $(57.57 \%)$ at a concentration of $0.40-4.15 \mathrm{mg} / \mathrm{mL}$ [82].

The acetylcholinesterase and butyrylcholinesterase inhibitory activities of $C$. racemosa and S. polycystum at various concentrations $(0.0125-0.2 \mathrm{mg} / \mathrm{mL})$ have been determined. Solvent extracts of $C$. racemosa and S. polycystum indicated anti-acetylcholinesterase activities with $\mathrm{IC}_{50}$ values ranging from $0.086-0.115 \mathrm{mg} / \mathrm{mL}$, while $C$. racemosa extracts indicated anti-butyrylcholinesterase activity with an $\mathrm{IC}_{50}$ value of $0.156 \mathrm{mg} / \mathrm{mL}$ [21].

A summary regarding the protective nature of the above-mentioned North Bornean seaweeds is shown in Table 2.

Table 2. Summary of the protective effects of North Bornean seaweeds.

\begin{tabular}{|c|c|c|c|c|c|c|c|}
\hline \multirow[t]{2}{*}{ Seaweed Species } & \multicolumn{7}{|c|}{ Protective Effects } \\
\hline & $\begin{array}{c}\text { Anti } \\
\text { Inflammatory }\end{array}$ & $\begin{array}{c}\text { Anti } \\
\text { Oxidant }\end{array}$ & $\begin{array}{c}\text { Anti } \\
\text { Microbial }\end{array}$ & $\begin{array}{c}\text { Anti } \\
\text { Cancer }\end{array}$ & $\begin{array}{l}\text { Anti-Obesity and } \\
\text { Cardiovascular } \\
\text { Protection }\end{array}$ & $\begin{array}{c}\text { Hepato } \\
\text { Protection }\end{array}$ & $\begin{array}{c}\text { Neuro- } \\
\text { Protection }\end{array}$ \\
\hline Kappaphycus alvarezii & + & + & + & + & + & + & + \\
\hline Eucheuma denticulatum & & + & + & + & + & & \\
\hline Caulerpa lentillifera & + & + & + & + & + & + & \\
\hline Caulerpa racemosa & + & + & + & + & & + & + \\
\hline Halymenia durvillaei & & + & + & + & & & \\
\hline Dictyota dichotoma & & + & + & + & & & + \\
\hline Sargassum polycystum & + & + & + & + & + & + & + \\
\hline
\end{tabular}

\section{Nutraceutical Profiling of North Bornean Seaweeds}

Seaweed nutraceutical bioactive compounds have great potential in biomedical and pharmaceutical applications [85-92]. Phytochemical analysis of Bornean seaweeds indicated the presence of various nutraceutical bioactive compounds with different properties, including phenolics, flavonoids, alkaloids, alcohols, steroids, fatty acids, terpenoids, etc. The nutraceutical bioactive compounds were identified in seaweed extracts by liquid chromatography-mass spectrometry (LCMS), gas chromatography-mass spectrometry (GCMS), and nuclear magnetic resonance (NMR) systems. The details are indicated in Table 3 and Figure 1a-g.

Table 3. List of some important nutraceutical bioactive compounds identified in North Bornean seaweeds.

\begin{tabular}{|c|c|c|c|}
\hline Species & Bioactive Compounds & Activity & References \\
\hline Kappaphycus alvarezii & $\begin{array}{c}\text { Phthalic anhydride } \\
\text { 1-Benzosuberone } \\
\text { 3,4-Ethylenedioxythiophene } \\
\text { Furoic acid } \\
\text { Coumarandione } \\
\text { 2-Benzofuran-4,7-dione } \\
\text { 2-Pentylthiophene } \\
\text { 2,3-Dihydropyrazolo[5,1- } \\
\text { b][1,3]thiazole-6-carbaldehyde } \\
\text { 1-(1,3-Thiazol-2-yl)-1H-tetrazole } \\
\text { 4-Chloro-1H-pyrazolo[3,4-b]pyridine } \\
\text { 4-Morpholinecarbonyl chloride } \\
\text { 3-Methylthiophene-2-carboxylic acid } \\
\text { 5-Pentyl-1,3,4-thiadiazol-2-amine } \\
\text { 3-Methyl-3,4-epoxysulfolane } \\
\text { Nonanal } \\
\text { 2-Tridecanone } \\
\text { 4-Aminopyrimidine }\end{array}$ & $\begin{array}{c}\text { Antimicrobial } \\
\text { Anticancer } \\
\text { Antitumor } \\
\text { Antimicrobial } \\
\text { Antitubercular } \\
\text { Antimicrobial } \\
\text { Antifungal } \\
\text { Anti-inflammatory, antibacterial, } \\
\text { anticancer } \\
\text { Antimicrobial } \\
\text { Anticancer, antioxidant } \\
\text { Antibacterial, antidepressant } \\
\text { Antibacterial } \\
\text { Antibacterial } \\
\text { Antifungal } \\
\text { Antifungal } \\
\text { Insecticide } \\
\text { Neuroprotection }\end{array}$ & $\begin{array}{l}{[93,94]} \\
{[94,95]} \\
{[96,97]}\end{array}$ \\
\hline
\end{tabular}


Table 3. Cont.

\begin{tabular}{|c|c|c|c|}
\hline Species & Bioactive Compounds & Activity & References \\
\hline \multirow{16}{*}{ Eucheuma denticulatum } & Docosahexaenoic acid & $\begin{array}{l}\text { Anticancer, cardiovascular protection, } \\
\text { anti-inflammatory }\end{array}$ & {$[86-88]$} \\
\hline & Eicosapentaenoic acid & Anticancer, cardiovascular protection & {$[86,88,98]$} \\
\hline & Palmitoleic acid & Anti-inflammatory & {$[86,99]$} \\
\hline & Antheraxanthin & Antioxidant & {$[100,101]$} \\
\hline & Astaxanthin & Anti-inflammatory, antioxidant & {$[100,102]$} \\
\hline & $\beta$-Carotene & Antioxidant & {$[100,103]$} \\
\hline & $\beta$-Cryptoxanthin & Anticancer, antioxidant & {$[100,104,105]$} \\
\hline & Dinoxanthin & Antioxidant & {$[100,106]$} \\
\hline & Diatoxanthin & Chemopreventive & {$[100,107]$} \\
\hline & Diadinoxanthin & Antioxidant & {$[100,106]$} \\
\hline & Fucoxanthin & Antitumor & {$[100,108]$} \\
\hline & Lutein & Antioxidant & {$[100,106]$} \\
\hline & Rubixanthin & Antioxidant & {$[100,109]$} \\
\hline & Zeaxanthin & Antioxidant & {$[100,106]$} \\
\hline & Eucalyptol & Antimicrobial, anti-inflammatory & {$[91,110,111]$} \\
\hline & Caryophyllene & Antioxidant, anticancer, antimicrobial & {$[91,92]$} \\
\hline \multirow[t]{13}{*}{ Halymenia durvillaei } & Palmitic acid & $\begin{array}{l}\text { Anti-inflammatory, antioxidant, } \\
\text { antiandrogenic 5- alpha-reductase } \\
\text { inhibitor nematicide, pesticide, } \\
\text { hypocholesterolemic }\end{array}$ & {$[17,91,112]$} \\
\hline & Oleic acid & $\begin{array}{l}\text { Quorum quenching and anti-biofilm } \\
\text { potential }\end{array}$ & {$[91,113]$} \\
\hline & Dodecanal & Antimicrobial & {$[91,114]$} \\
\hline & Heptadecanoic acid & Anticancer & {$[91,115]$} \\
\hline & Pentadecanoic acid & Anticancer & {$[91,116]$} \\
\hline & Myristic acid & Larvicidal and repellent & {$[91,117]$} \\
\hline & Docosahexaenoic acid & $\begin{array}{c}\text { Anticancer, cardiovascular protection, } \\
\text { anti-inflammatory }\end{array}$ & {$[86-88]$} \\
\hline & Eicosapentaenoic acid & Anticancer & {$[86,98]$} \\
\hline & Palmitoleic acid & Anti-inflammatory & {$[86,99]$} \\
\hline & Astaxanthin & Anti-inflammatory, antioxidant & {$[100,102]$} \\
\hline & $\beta$-Carotene, & Antioxidant & {$[100,103]$} \\
\hline & $\beta$-Cryptoxanthin & Anticancer, antioxidant & {$[100,104,105]$} \\
\hline & Canthaxanthin & $\begin{array}{l}\text { Antioxidant, anti-inflammatory, } \\
\text { neuroprotection }\end{array}$ & {$[100,118]$} \\
\hline \multirow[t]{11}{*}{ Caulerpa lentillifera } & Zeaxanthin & Antioxidant & {$[100,106]$} \\
\hline & Oleic acid & $\begin{array}{l}\text { Antioxidant, cardiovascular } \\
\text { protection, hepatic protection }\end{array}$ & {$[119,120]$} \\
\hline & Pentadecanoic acid & Anticancer & {$[116,119]$} \\
\hline & Myristic acid & Antidiabetic, anti-inflammatory & {$[119,121]$} \\
\hline & Behenic acid & Anti-obesity & {$[119,122]$} \\
\hline & Palmitic acid & Antitumor & {$[119,123]$} \\
\hline & Limonene & Antiparasitic & {$[94,124]$} \\
\hline & Heneicosane & $\begin{array}{c}\text { Anti-inflammatory, analgesic, } \\
\text { antipyretic }\end{array}$ & {$[94,125]$} \\
\hline & Eicosane & $\begin{array}{l}\text { Anti-inflammatory, analgesic, } \\
\text { antipyretic }\end{array}$ & {$[94,125]$} \\
\hline & Pentadecane & $\begin{array}{c}\text { Anti-inflammatory, analgesic, } \\
\text { antipyretic }\end{array}$ & {$[94,125]$} \\
\hline & Azulene & Anti-inflammatory & {$[94,126]$} \\
\hline
\end{tabular}


Table 3. Cont.

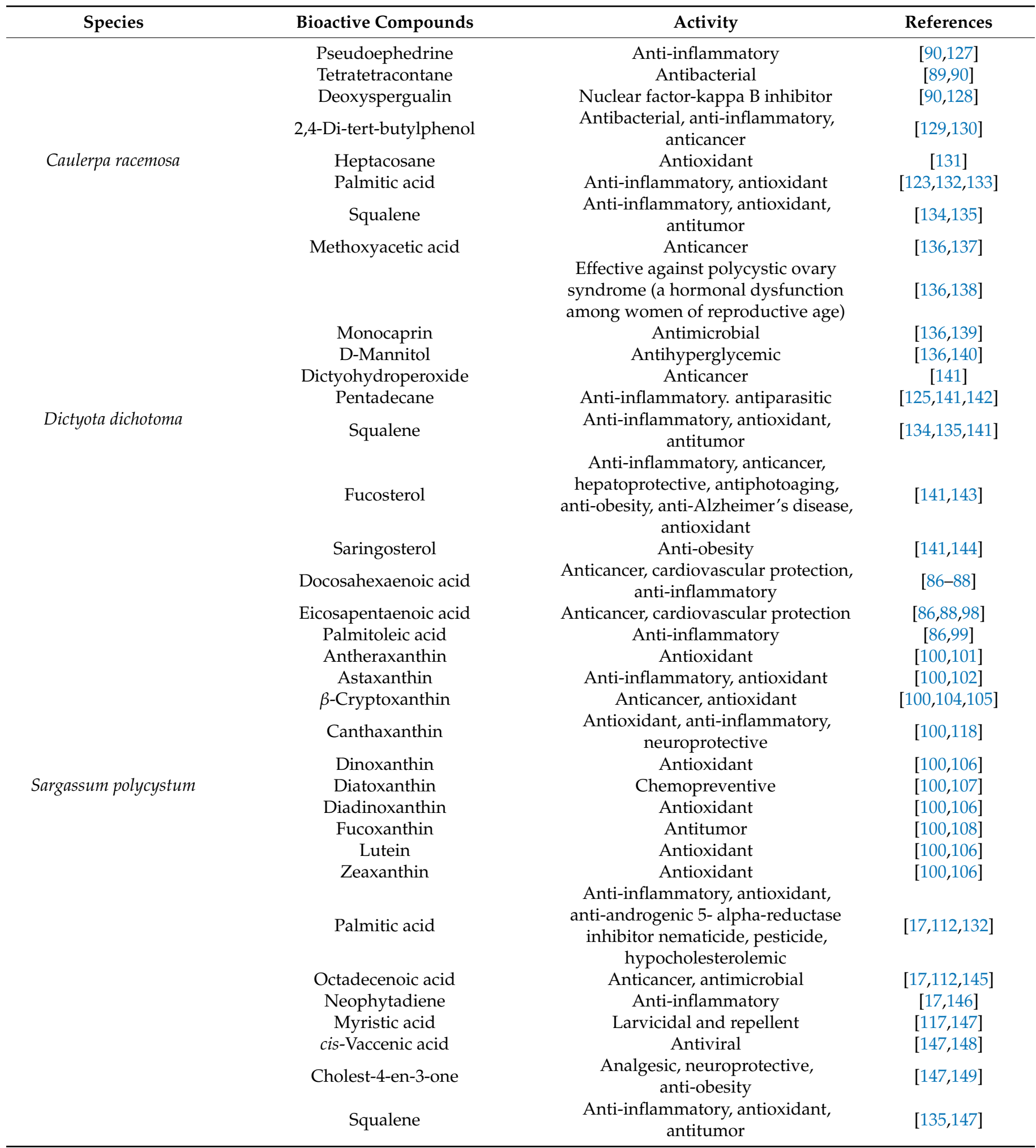


<smiles>O=C1OC(=O)c2ccccc21</smiles>

Phthalic anhydride<smiles>O=C1Oc2ccccc2C1=O</smiles>

Coumarandione<smiles>c1scc2c1OCCO2</smiles>

3,4-Ethylenedioxythiophene<smiles>Clc1ccnc2[nH]ncc12</smiles>

4-Chloro-1H-pyrazolo[3,4-b]pyridine<smiles>O=C1C=CC(=O)c2cocc21</smiles>

2-Benzofuran-4,7-dione<smiles>O=C1CCCCc2ccccc21</smiles>

1-Benzosuberone<smiles>O=C(O)c1ccco1</smiles>

Furoic acid<smiles>CC12CS(=O)(=O)CC1O2</smiles>

3-methyl-3,4-epoxysulfolane<smiles>CC(=O)N1CCOCC1</smiles>

4-Morpholinecarbonyl chloride<smiles>CCCCCc1cccs1</smiles>

2-Pentylthiophene<smiles>O=C(O)c1cccs1</smiles>

3-Methylthiophene-2-carboxylic acid

Nonanal
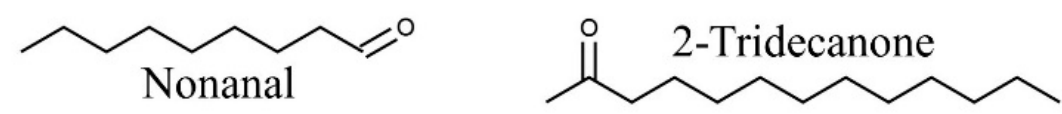<smiles>Nc1ccncn1</smiles>

4-Aminopyrimidine 2,3-Dihydropyrazolo[5,1-b][1,3]thiazole-6-carbaldehyde<smiles>c1csc(-n2cnnn2)n1</smiles>

1-(1,3-Thiazol-2-yl)-1H-tetrazole<smiles>CCCCCc1nnc(N)s1</smiles>

5-Pentyl-1,3,4-thiadiazol-2-amine

(a)

Figure 1. Cont. 


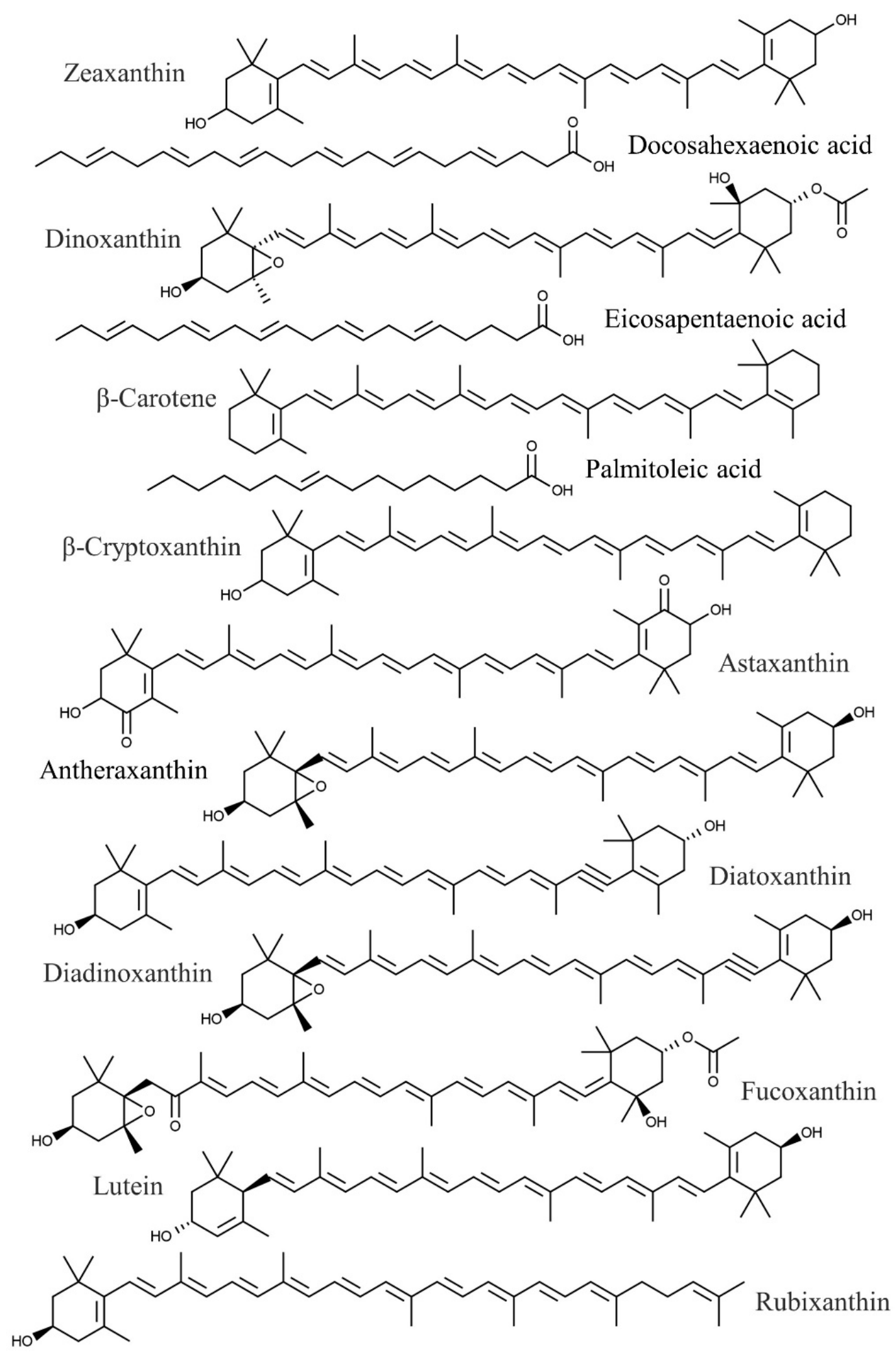

(b)

Figure 1. Cont. 


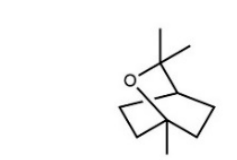

Eucalyptol

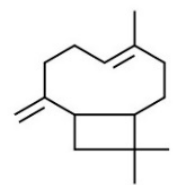

Caryophyllene
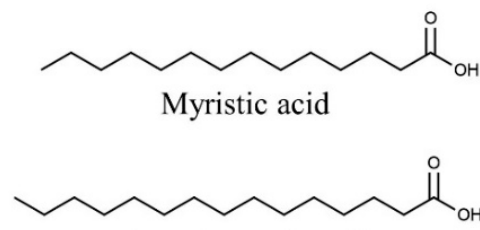

Pentadecanoic acid<smiles>CCCCCCCCCCCCCCCC(=O)O</smiles>

Palmitic acid

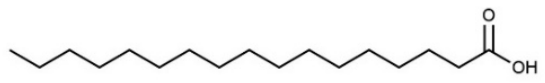

Heptadecanoic acid

Oleic acid

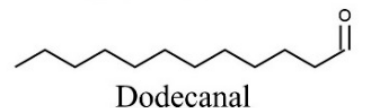

(c)

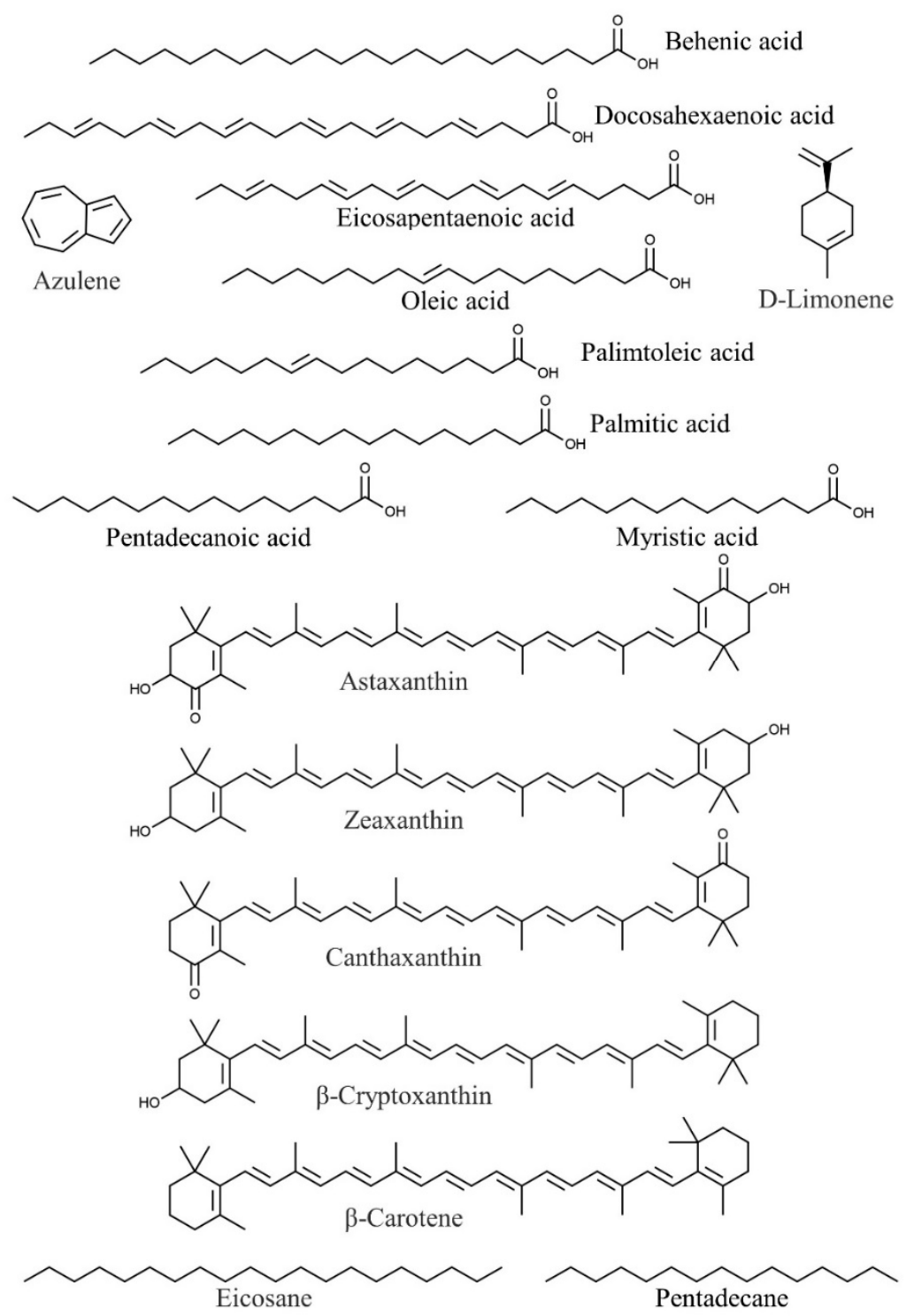

(d)

Figure 1. Cont. 
<smiles>CCCCCCCCCC(=O)OCC(O)CO</smiles><smiles>CC(C)(C)c1ccc(O)c(C(C)(C)C)c1</smiles>

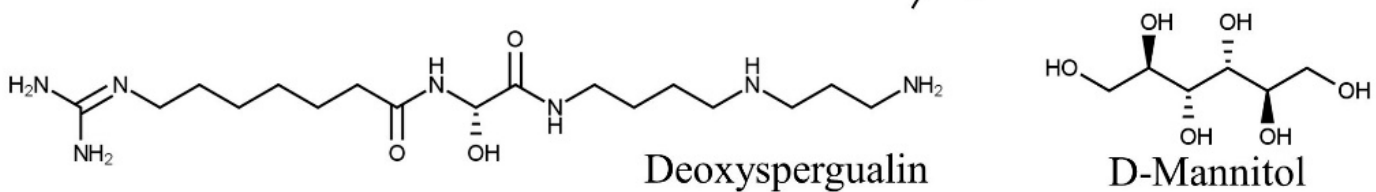<smiles>CN[C@H](C)[C@H](O)c1ccccc1</smiles>

Pseudoephedrine<smiles>CC(C)=CCC/C(C)=C/CC/C(C)=C/CC/C=C(\C)CC/C=C(\C)CCC=C(C)C</smiles>

$\prod_{0}^{\text {HO }}{ }^{\circ}{ }^{\prime}$ Methoxyacetic acid

Palmitic acid<smiles>CCCCCCCCCCCCCCCCCCCCC[14CH2]O[14CH3]</smiles>

Tetratetracontane

(e)<smiles>C/C=C(/CC[C@H](C)C1CCC2C3CC=C4C[C@@H](O)CC[C@]4(C)C3CC[C@@]21C)C(C)C</smiles><smiles>C=CC(O)(CC[C@@H](C)C1CCC2C3CC=C4C[C@@H](O)CC[C@]4(C)C3CC[C@@]21C)C(C)C</smiles><smiles>C=C1CC[C@H](C(C)CC[C@H](O)C(C)(C)Cl)[C@@H](O)[C@@H]2[C@H]1C=C[C@]2(C)OO</smiles>

Dictyohydroperoxide<smiles>CCCCCCCCCCCCCCCCCCCCCCC(C)=CCCC(C)=CCCC(C)=CCCC(C)=CCCC=C(C)C</smiles>

(f)

Figure 1. Cont. 


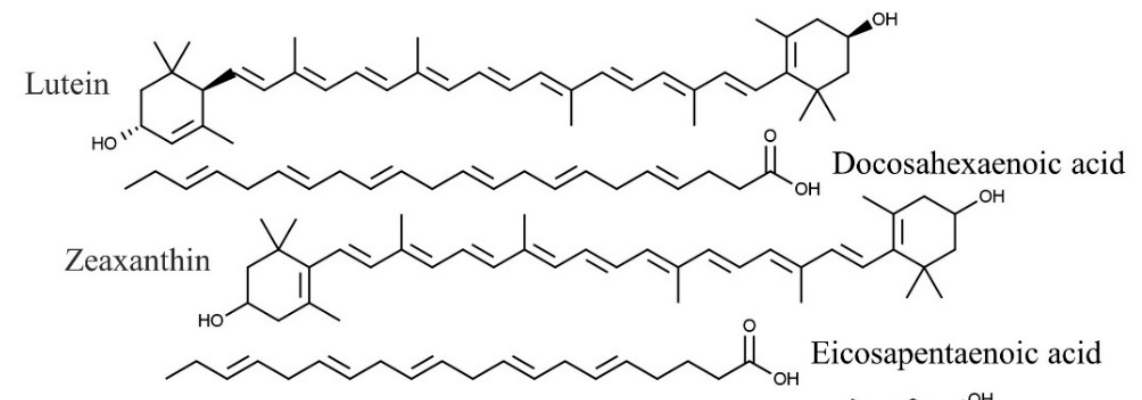

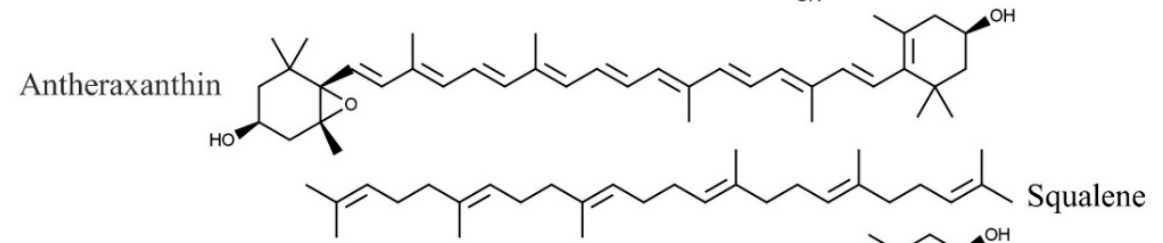

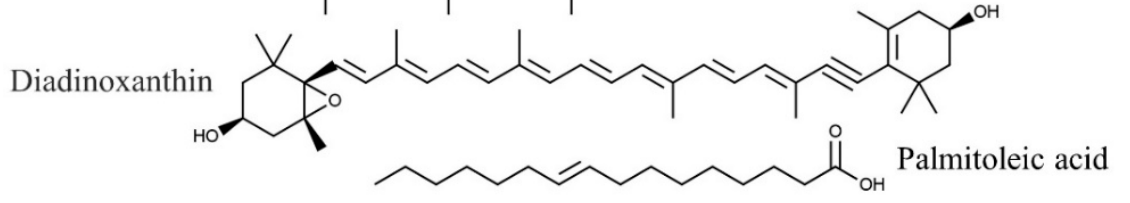<smiles>CCCCCC/C=C\CCCCCCCCCC(=O)O</smiles>

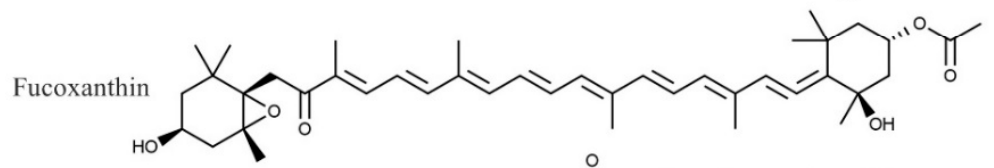

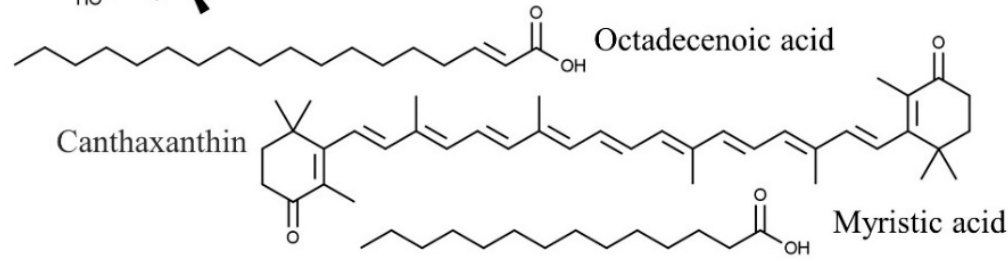<smiles>CCCCCCCCCCCCCCC(=O)OC1=C(C)C[C@@H](O)CC1(C)C</smiles><smiles>CC1=C(/C=C/C(C)=C/C=C/C=C(C)/C=C/C=C/C=C(C)/C=C/C=C(C)/C=C/C2=C(C)CC(O)CC2(C)C)C(C)(C)CCC1</smiles>

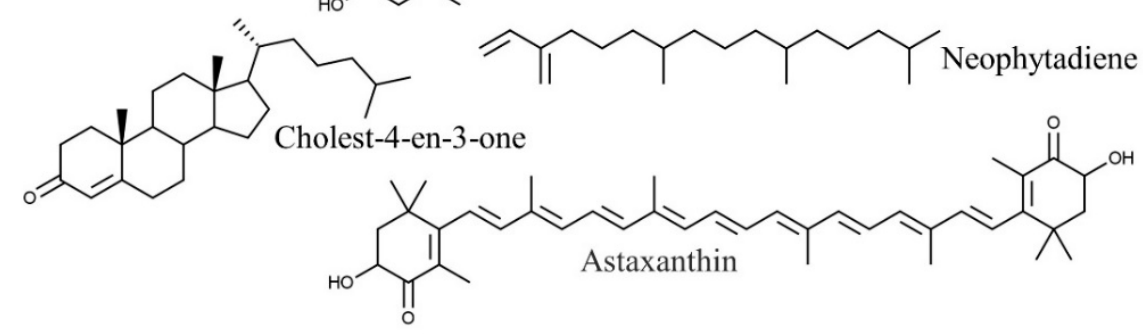

(g)

Figure 1. Phytochemical compounds of (a) Kappaphycus alvarezii, (b) Eucheuma denticulatum, (c) Halymenia durvillaei, (d) Caulerpa lentillifera, (e) Caulerpa racemosa, (f) Dictyota dichotoma, and (g) Sargassum polycystum. 


\section{Methodology}

The information was retrieved from multiple internet databases such as ScienceDirect, PubMed, Wiley, ACS publications, etc., and registers including theses and proceedings. Records were searched with keywords related to seaweed, North Borneo, distribution, taxonomy, bioactivity, secondary metabolites, and diseases. Around 250 records approximately from the year 2000 to 2021 were retrieved and screened. Among these, about 100 records were excluded due to being out of the scope of the review. Eventually, a total of 149 records were adopted for the current review paper, and data from organizations such as the World Health Organization were included as well.

\section{Conclusions}

In the current review, the protective effects of North Bornean seaweeds in terms of anti-inflammatory, antioxidant, antimicrobial, anticancer, anti-obesity and cardiovascular protection, neuroprotection, and renal protection as well as hepatic protection were described and followed by nutraceutical profiling. The protective roles of the seaweeds might be due to the presence of a wide variety of nutraceuticals including phthalic anhydride, 3,4ethylenedioxythiophene, 2-pentylthiophene, furoic acid (K. alvarezii), eicosapentaenoic acid, palmitoleic acid, fucoxanthin, $\beta$-carotene (E. denticulatum), eucalyptol, oleic acid, dodecanal, pentadecane, (H. durvillaei), canthaxanthin, pentadecanoic acid, eicosane (C. lentillifera), pseudoephedrine, palmitic acid, monocaprin (C. racemosa), dictyohydroperoxide, squalene, fucosterol, saringosterol (D. dichotoma) and lutein, neophytadiene, cholest-4-en-3-one, and cis-vaccenic acid (S. polycystum).

Despite their excellent pharmacological characteristics, only K. alvarezii and E. denticulatum are widely cultivated, developed as a functional food source, and used for carrageenans production. Locally, C. lentillifera and C. racemosa are also consumed as a nutrition source. For future perspectives, studies on functional food development and cultivation techniques are highly recommended. Furthermore, extensive studies on the seaweed isolates are needed to understand their bioactivity and mechanisms of action, while highlighting their commercialization potential.

Author Contributions: M.D.S., S.R.M.S. and Y.S.Y. contributed to the conceptualization, discussion and writing of this review manuscript. B.A.V.M., W.H.Z. and C.G. contributed to the discussion of this review manuscript. The final version of the manuscript was approved by all authors. All authors have read and agreed to the published version of the manuscript.

Funding: This study was funded by FRGS/1/2018/STG03/UMS/02/2 to BAVM and the Universiti Malaysia Sabah project (PRF No. 0011-2019).

Conflicts of Interest: The authors declare no conflict of interest.

\section{References}

1. Hamed, I.; Özogul, F.; Özogul, Y.; Regenstein, J.M. Marine bioactive compounds and their health benefits: A review. Compr. Rev. Food Sci. Food Saf. 2015, 14, 446-465. [CrossRef]

2. Ito, K.; Hori, K. Seaweed: Chemical composition and potential food use. Food Rev. Int. 1989, 5, 101-144. [CrossRef]

3. Saravanan, K.R.; Ilangovan, K.; Khan, A.B. Floristic and macro faunal diversity of Pondicherry mangroves, South India. Trop. Ecol. 2008, 49, 91-94.

4. Dmytryk, A.; Tuhy, Ł.; Chojnacka, K. Algae as source of pharmaceuticals. In Prospects and Challenges in Algal Biotechnology; Springer: Singapore, 2017; pp. 295-310, ISBN 9789811019500.

5. Murugan, K.; Iyer, V.V. Differential growth inhibition of cancer cell lines and antioxidant activity of extracts of red, brown, and green marine algae. In Vitro Cell. Dev. Biol.-Anim. 2013, 49, 324-334. [CrossRef] [PubMed]

6. Melanie, H.; Taarji, N.; Zhao, Y.; Khalid, N.; Neves, M.A.; Kobayashi, I.; Tuwo, A.; Nakajima, M. Formulation and characterisation of $\mathrm{O} / \mathrm{W}$ emulsions stabilised with modified seaweed polysaccharides. Int. J. Food Sci. Technol. 2020, 55, 211-221. [CrossRef]

7. Hussin, H.; Khoso, A. Seaweed cultivation and coastal communities in Malaysia: An overview. Asian Fish. Sci. 2017, 30, 87-100. [CrossRef]

8. Hurtado, A.Q.; Gerung, G.S.; Yasir, S.; Critchley, A.T. Cultivation of tropical red seaweeds in the BIMP-EAGA region. J. Appl. Phycol. 2014, 26, 707-718. [CrossRef] 
9. Matanjun, P.; Mohamed, S.; Mustapha, N.M.; Muhammad, K.; Ming, C.H. Antioxidant activities and phenolics content of eight species of seaweeds from north Borneo. J. Appl. Phycol. 2008, 20, 367-373. [CrossRef]

10. Guiry, M.D.; Guiry, G. Algaebase: Listing the World's Algae. Available online: https://www.algaebase.org/ (accessed on 23 September 2021).

11. Lim, C.L.; Koh, R.Y.; Haw, T.Y.; Boudville, L.A. Antioxidant activity of the Sea-Bird Nest (Eucheuma Cottonii) and its radical scavenging effect on human keratinocytes. J. Med. Bioeng. 2015, 4, 461-465. [CrossRef]

12. Balasubramaniam, V.; Mustar, S.; Mustafa Khalid, N.; Abd Rashed, A.; Mohd Noh, M.F.; Wilcox, M.D.; Chater, P.I.; Brownlee, I.A.; Pearson, J.P. Inhibitory activities of three Malaysian edible seaweeds on lipase and $\alpha$-amylase. J. Appl. Phycol. 2013, 25, 1405-1412. [CrossRef]

13. Pereira, L.; Valado, A. The seaweed diet in prevention and treatment of the Neurodegenerative diseases. Mar. Drugs 2021, 19, 128. [CrossRef] [PubMed]

14. Bauer, S.; Jin, W.; Zhang, F.; Linhardt, R.J. The application of seaweed polysaccharides and their derived products with potential for the treatment of Alzheimer's disease. Mar. Drugs 2021, 19, 89. [CrossRef] [PubMed]

15. Thanigaivel, S.; Chandrasekaran, N.; Mukherjee, A.; Thomas, J. Seaweeds as an alternative therapeutic source for aquatic disease management. Aquaculture 2016, 464, 529-536. [CrossRef]

16. Abu Bakar, N.; Anyanji, V.U.; Mustapha, N.M.; Lim, S.L.; Mohamed, S. Seaweed (Eucheuma cottonii) reduced inflammation, mucin synthesis, eosinophil infiltration and MMP-9 expressions in asthma-induced rats compared to Loratadine. J. Funct. Foods 2015, 19, 710-722. [CrossRef]

17. Buwono, N.R.; Risjani, Y.; Arsad, S. Anti-inflammatory and analgesic activity from brown algae Sargassum polycystum. J. Pharm. Sci. Res. 2018, 10, 2092-2096.

18. Saito, H.; Lal, T.M. Antimycotic activity of seaweed extracts (Caulerpa lentillifera and Eucheuma cottonii) against two genera of marine oomycetes, Lagenidium spp. And Haliphthoros spp. Biocontrol Sci. 2019, 24, 73-80. [CrossRef] [PubMed]

19. Noda, H.; Amano, H.; Arashima, K.; Nisizawa, K. Antitumor activity of marine algae. Hydrobiologia 1990, 204-205, 577-584 [CrossRef]

20. Matanjun, P.; Mohamed, S.; Muhammad, K.; Mustapha, N.M. Comparison of cardiovascular protective effects of tropical seaweeds, Kappaphycus alvarezii, Caulerpa lentillifera, and Sargassum polycystum, on high-cholesterol/high-fat diet in rats. J. Med. Food 2010, 13, 792-800. [CrossRef] [PubMed]

21. Gany, S.A.; Ching, S.; Gan, S.Y. Antioxidative, anticholinesterase and anti-neuroinflammatory properties of Malaysian brown and green seaweeds. World Acad. Sci. Eng. Technol. 2014, 8, 1269-1275.

22. Raghavendran, H.R.B.; Sathivel, A.; Devaki, T. Hepatoprotective nature of seaweed alcoholic extract on acetaminophen induced hepatic oxidative stress. J. Health Sci. 2004, 50, 42-46. [CrossRef]

23. Kotas, M.E.; Medzhitov, R. Homeostasis, inflammation, and disease susceptibility. Cell 2015, 160, 816-827. [CrossRef] [PubMed]

24. Medzhitov, R. Origin and physiological roles of inflammation. Nature 2008, 454, 428-435. [CrossRef] [PubMed]

25. Dray, A. Inflammatory mediators of pain. Br. J. Anaesth. 1995, 75, 125-131. [CrossRef]

26. Hotamisligil, G.S. Inflammation and metabolic disorders. Nature 2006, 444, 860-867. [CrossRef] [PubMed]

27. Sun, Y.; Liu, Z.; Song, S.; Zhu, B.; Zhao, L.; Jiang, J.; Liu, N.; Wang, J.; Chen, X. Anti-inflammatory activity and structural identification of a sulfated polysaccharide CLGP4 from Caulerpa lentillifera. Int. J. Biol. Macromol. 2020, 146, 931-938. [CrossRef]

28. Ribeiro, N.A.; Abreu, T.M.; Chaves, H.V.; Bezerra, M.M.; Monteiro, H.S.A.; Jorge, R.J.B.; Benevides, N.M.B. Sulfated polysaccharides isolated from the green seaweed Caulerpa racemosa plays antinociceptive and anti-inflammatory activities in a way dependent on HO-1 pathway activation. Inflamm. Res. 2014, 63, 569-580. [CrossRef]

29. Yoon, W.J.; Ham, Y.M.; Kim, K.N.; Park, S.Y.; Lee, N.H.; Hyun, C.G.; Lee, W.J. Anti-inflammatory activity of brown alga Dictyota dichotoma in murine macrophage RAW 264.7 cells. J. Med. Plants Res. 2009, 3, 001-008. [CrossRef]

30. Pizzino, G.; Irrera, N.; Cucinotta, M.; Pallio, G.; Mannino, F.; Arcoraci, V.; Squadrito, F.; Altavilla, D.; Bitto, A. Oxidative stress: Harms and benefits for human health. Oxid. Med. Cell. Longev. 2017, 2017, 1-13. [CrossRef] [PubMed]

31. Shah, M.D.; Seelan Sathiya Seelan, J.; Iqbal, M. Phytochemical investigation and antioxidant activities of methanol extract, methanol fractions and essential oil of Dillenia suffruticosa leaves. Arab. J. Chem. 2020, 13, 7170-7182. [CrossRef]

32. Shah, M.D.; Iqbal, M. Diazinon-induced oxidative stress and renal dysfunction in rats. Food Chem. Toxicol. 2010, 48, 3345-3353. [CrossRef]

33. Shah, M.D.; Iqbal, M. Antioxidant activity, phytochemical analysis and total polyphenolics content of essential oil, methanol extract and methanol fractions from Commelina nudiflora. Int. J. Pharm. Pharm. Sci. 2018, 10, 36. [CrossRef]

34. Palanisamy, S.; Vinosha, M.; Manikandakrishnan, M.; Anjali, R.; Rajasekar, P.; Marudhupandi, T.; Manikandan, R.; Vaseeharan, B.; Prabhu, N.M. Investigation of antioxidant and anticancer potential of fucoidan from Sargassum polycystum. Int. J. Biol. Macromol. 2018, 116, 151-161. [CrossRef] [PubMed]

35. Yap, W.F.; Tay, V.; Tan, S.H.; Yow, Y.Y.; Chew, J. Decoding antioxidant and antibacterial potentials of Malaysian green seaweeds: Caulerpa racemosa and Caulerpa lentillifera. Antibiotics 2019, 8, 152. [CrossRef] [PubMed]

36. NIH Understanding Emerging and Re-Rmerging Infectious Diseases-National Institute of Health (NIH) Curriculum Supplement Series-NCBI Bookshelf. Available online: https:/ / www.ncbi.nlm.nih.gov/books/NBK20370/ (accessed on 14 September 2021) 
37. Teo, B.S.X.; Gan, R.Y.; Abdul Aziz, S.; Sirirak, T.; Mohd Asmani, M.F.; Yusuf, E. In vitro evaluation of antioxidant and antibacterial activities of Eucheuma cottonii extract and its in vivo evaluation of the wound-healing activity in mice. J. Cosmet. Dermatol. 2021, 20, 993-1001. [CrossRef] [PubMed]

38. Iskandar, Y.; Halimah, E.; Shifa, N.; Fushilla, Z.; Silvana, G.; Zuhrotun, A. Activity of reed algae (Eucheuma Cottonii) against some Bacteria and Fungi. J. Pharm. Sci. Res. 2019, 11, 2362-2366.

39. Nakamura, K.; Nakamura, M.; Hatai, K. Zafran Lagenidium infection in eggs and larvae of mangrove crab (Scylla serrata) produced in Indonesia. Mycoscience 1995, 36, 399-404. [CrossRef]

40. Lee, Y.N.; Hatai, K.; Kurata, O. Haliphthoros sabahensis sp. nov. isolated from mud crab Scylla tranquebarica eggs and larvae in Malaysia. Fish Pathol. 2017, 52, 31-37. [CrossRef]

41. Sato, Y.; Morimoto, K.; Hirayama, M.; Hori, K. High mannose-specific lectin (KAA-2) from the red alga Kappaphycus alvarezii potently inhibits influenza virus infection in a strain-independent manner. Biochem. Biophys. Res. Commun. 2011, 405, 291-296. [CrossRef]

42. Safitri, A.; Srihardyastutie, A.; Roosdiana, A.; Sutrisno, S. Antibacterial activity and phytochemical analysis of edible seaweed Eucheuma spinosum against Staphyloccocus aureus. J. Pure Appl. Chem. Res. 2018, 7, 308-315. [CrossRef]

43. Julyasih, K.S.; Purnawati, A. Antifungal activity of seaweed against Aspergillus flavus. In Proceedings of the Nusantara Science and Technology Proceedings, Galaxy Science, Surabaya, Indonesia, 23 November 2018; pp. 11-13. [CrossRef]

44. Montanha, J.A.; Bourgougnon, N.; Boustie, J.; Amoros, M. Antiviral activity of carrageenans from marine red algae. Am. J. Pharm 2009, 28, 443-451.

45. Atienza, J.O.; Evangelista, R.A. Taxonomy and Screening for Antimicrobial Activities of Selected Marine Algal Species from Talaga East, Mabini, Batangas. Available online: https://animorepository.dlsu.edu.ph/etd_bachelors/3840 (accessed on 26 October 2021).

46. Klongklaew, N.; Praiboon, J.; Tamtin, M.; Srisapoome, P. Antibacterial and antiviral activities of local Thai green macroalgae crude extracts in pacific white shrimp (litopenaeus vannamei). Mar. Drugs 2020, 18, 140. [CrossRef] [PubMed]

47. Lightner, D.V. Virus diseases of farmed shrimp in the Western Hemisphere (the Americas): A review. J. Invertebr. Pathol. 2011, 106, 110-130. [CrossRef] [PubMed]

48. Flegel, T.W. A future vision for disease control in shrimp aquaculture. J. World Aquac. Soc. 2019, 50, 249-266. [CrossRef]

49. Chan, Y.S.; Ong, C.W.; Chuah, B.L.; Khoo, K.S.; Chye, F.Y.; Sit, N.W. Antimicrobial, antiviral and cytotoxic activities of selected marine organisms collected from the coastal areas of Malaysia. J. Mar. Sci. Technol. 2018, 26, 128-136. [CrossRef]

50. Simon, F.; Javelle, E.; Oliver, M.; Leparc-Goffart, I.; Marimoutou, C. Chikungunya virus infection. Curr. Infect. Dis. Rep. 2011, 13, 218-228. [CrossRef] [PubMed]

51. Demirel, Z.; Yilmaz-Koz, F.F.; Karabay-Yavasoglu, U.N.; Ozdemir, G.; Sukatar, A. Antimicrobial and antioxidant activity of brown algae from the Aegean Sea. J. Serb. Chem. Soc. 2009, 74, 619-628. [CrossRef]

52. Thirumaran, G.; Vijayabaskar, P.; Anantharaman, P. Antibacterial and antifugal activities of brown marine macroalge (Dictyota dichotoma) from the Gulf of Mannar biosphere reserve. Environ. Ecolol. 2006, 24, 37-40.

53. Rabanal, M.; Ponce, N.M.A.; Navarro, D.A.; Gómez, R.M.; Stortz, C.A. The system of fucoidans from the brown seaweed Dictyota dichotoma: Chemical analysis and antiviral activity. Carbohydr. Polym. 2014, 101, 804-811. [CrossRef] [PubMed]

54. Whitley, R.J.; Roizman, B. Herpes simplex virus infections. Lancet 2001, 357, 1513-1518. [CrossRef]

55. Muckelbauer, J.K.; Kremer, M.; Minor, I.; Diana, G.; Dutko, F.J.; Groarke, J.; Pevear, D.C.; Rossmann, M.G. The structure of coxsackievirus B3 at 3.5 å resolution. Structure 1995, 3, 653-667. [CrossRef]

56. Thangaraju, N.; Venkatalakshmi, R.P.; Chinnasamy, A.; Kannaiyan, P. Synthesis of silver nanoparticles and the antibacterial and anticancer activities of the crude extract of Sargassum polycystum C. Agardh. Nano Biomed. Eng. 2012, 4, 89-94. [CrossRef]

57. Rattaya, S.; Benjakul, S.; Prodpran, T. Extraction, antioxidative, and antimicrobial activities of brown seaweed extracts, Turbinaria ornata and Sargassum polycystum, grown in Thailand. Int. Aquat. Res. 2015, 7, 1-16. [CrossRef]

58. Sawadogo, W.; Schumacher, M.; Teiten, M.-H.; Cerella, C.; Dicato, M.; Diederich, M. A Survey of Marine natural compounds and their dserivatives with anti-cancer activity reported in 2011. Molecules 2013, 18, 3641-3673. [CrossRef]

59. Maeda, R.; Ida, T.; Ihara, H.; Sakamoto, T. Induction of apoptosis in MCF-7 cells by $\beta-1,3$-xylooligosaccharides prepared from Caulerpa lentillifera. Biosci. Biotechnol. Biochem. 2012, 76, 1032-1034. [CrossRef] [PubMed]

60. Ji, H.; Shao, H.; Zhang, C.; Hong, P.; Xiong, H. Separation of the polysaccharides in Caulerpa racemosa and their chemical composition and antitumor activity. J. Appl. Polym. Sci. 2008, 110, 1435-1440. [CrossRef]

61. Miranda, M.A.; Chiou, C.T.; Tayo, L.L.; Hsieh, C.L.; Tsai, P.W. In vitro anticancer activities of selected Philippine seaweeds against several cancer cell lines. Plant Cell Biotechnol. Mol. Biol. 2021, 22, 108-114.

62. El-Shaibany, A.; AL-Habori, M.; Al-Maqtari, T.; Al-Mahbashi, H. The Yemeni brown algae Dictyota dichotoma exhibit high in vitro anticancer activity independent of its antioxidant capability. Biomed Res. Int. 2020, 2020, 1-9. [CrossRef] [PubMed]

63. Arsianti, A.A.; Fadilah, F.; Fatmawaty, Y.; Wibisono, L.K.; Kusmardi, S.; Azizah, N.N.; Putrianingsih, R.; Murniasih, T.; Rasyid, A.; Pangestuti, R. Phytochemical composition and anticancer activity of seaweeds Ulva lactuca and Eucheuma cottonii against breast MCF-7 and colon HCT-116 cells. Asian J. Pharm. Clin. Res. 2016, 9, 115-119. [CrossRef]

64. Palanisamy, S.; Vinosha, M.; Marudhupandi, T.; Rajasekar, P.; Prabhu, N.M. Isolation of fucoidan from Sargassum polycystum brown algae: Structural characterization, in vitro antioxidant and anticancer activity. Int. J. Biol. Macromol. 2017, 102, 405-412. [CrossRef] [PubMed] 
65. Bao, J.X.; Li, K.H.; Yi, N.Z.; Jeong, H.L.; Chang, K.S. In vitro inhibitory effect of triterpenoidal saponins from Platycodi radix on pancreatic lipase. Arch. Pharm. Res. 2005, 28, 180-185. [CrossRef]

66. Cercato, C.; Fonseca, F.A. Cardiovascular risk and obesity. Diabetol. Metab. Syndr. 2019, 11, 74. [CrossRef] [PubMed]

67. Asrani, S.K.; Larson, J.J.; Yawn, B.; Therneau, T.M.; Kim, W.R. Underestimation of liver-related mortality in the United States. Gastroenterology 2013, 145, 375-382.e2. [CrossRef] [PubMed]

68. Mokdad, A.A.; Lopez, A.D.; Shahraz, S.; Lozano, R.; Mokdad, A.H.; Stanaway, J.; Murray, C.J.; Naghavi, M. Liver cirrhosis mortality in 187 countries between 1980 and 2010: A systematic analysis. BMC Med. 2014, 12. [CrossRef]

69. Rehm, J.; Mathers, C.; Popova, S.; Thavorncharoensap, M.; Teerawattananon, Y.; Patra, J. Global burden of disease and injury and economic cost attributable to alcohol use and alcohol-use disorders. Lancet 2009, 373, 2223-2233. [CrossRef]

70. Morgan, M.Y. The prognosis and outcome of alcoholic liver disease. Alcohol Alcohol Suppl. 1994, 2, 335-343. [PubMed]

71. World Health Organization. Global Burden of Disease Estimates for 2000-2012; World Health Organization: Geneva, Switzerland, 2018.

72. Asrani, S.K.; Devarbhavi, H.; Eaton, J.; Kamath, P.S. Burden of liver diseases in the world. J. Hepatol. 2019, 70, 151-171. [CrossRef]

73. Björnsson, E.S.; Bergmann, O.M.; Björnsson, H.K.; Kvaran, R.B.; Olafsson, S. Incidence, presentation, and outcomes in patients with drug-induced liver Injury in the general population of Iceland. Gastroenterology 2013, 144, 1419-1425.e3. [CrossRef]

74. Hsu, P.C.; Guo, Y.L. Antioxidant nutrients and lead toxicity. Toxicology 2002, 180, 33-44. [CrossRef]

75. Shah, M.D.; D'Souza, U.J.A.; Iqbal, M. The potential protective effect of Commelina nudiflora L. against carbon tetrachloride (CCl4)-induced hepatotoxicity in rats, mediated by suppression of oxidative stress and inflammation. Environ. Health Prev. Med. 2017, 22, 1-19. [CrossRef]

76. Wardani, G.; Farida, N.; Andayani, R.; Kuntoro, M.; Sudjarwo, S. The potency of red seaweed (Eucheuma cottonii) extracts as hepatoprotector on lead acetate-induced hepatotoxicity in mice. Pharmacognosy Res. 2017, 9, 282-286. [CrossRef]

77. Shah, M.D.; Gnanaraj, C.; Haque, A.E.; Iqbal, M. Antioxidative and chemopreventive effects of Nephrolepis biserrata against carbon tetrachloride $\left(\mathrm{CCl}_{4}\right)$-induced oxidative stress and hepatic dysfunction in rats. Pharm. Biol. 2015, 53, 31-39. [CrossRef] [PubMed]

78. Codorniz, K.D.; Marquina, R.E.M.; Nolasco, A.D.G.; Palencia, P.D.D.; Mata, S.B. Evaluation of the hepatoprotective effect of methanolic extract of Caulerpa lentillifera against acetaminophen-induced liver toxicity in juvenile zebrafish (Danio rerio). J. Ilm. Farm. 2020, 16, 31-38. [CrossRef]

79. Azam, M.; Hira, K.; Qureshi, S.A.; Khatoon, N.; Ara, J.; Ehteshamul-Haque, S. Ameliorative effect of marine macro-algae against carbon tetrachloride (CCl4) induced hepatic fibrosis and associated complications in rats. Turk. J. Pharm. Sci. 2021, 1-8. [CrossRef]

80. Bălașa, A.F.; Chircov, C.; Grumezescu, A.M. Marine bio compounds for neuroprotection-A review. Mar. Drugs 2020, 18, 290. [CrossRef] [PubMed]

81. Tirtawijaya, G.; Mohibbullah, M.; Meinita, M.D.N.; Moon, I.S.; Hong, Y.K. The tropical carrageenophyte Kappaphycus alvarezii extract promotes axodendritic maturation of hippocampal neurons in primary culture. J. Appl. Phycol. 2018, 30, 3233-3241. [CrossRef]

82. Suganthy, N.; Karutha Pandian, S.; Pandima Devi, K. Neuroprotective effect of seaweeds inhabiting South Indian coastal area (Hare Island, Gulf of Mannar Marine Biosphere Reserve): Cholinesterase inhibitory effect of Hypnea valentiae and Ulva reticulata. Neurosci. Lett. 2010, 468, 216-219. [CrossRef]

83. Stoppe, G.; Sandholzer, H.; Staedt, J.; Winter, S.; Kiefer, J.; Rüther, E. Prescribing practice with cognition enhancers in outpatient care: Are there differences regarding type of Dementia? -Results of a representative survey in Lower Saxony, Germany. Pharmacopsychiatry 2007, 29, 150-155. [CrossRef]

84. Zarotsky, V.; Sramek, J.J.; Cutler, N.R. Galantamine hydrobromide: An agent for Alzheimer's disease. Am. J. Health Pharm. 2003, 60, 446-452. [CrossRef]

85. Purbosari, N.; Warsiki, E.; Syamsu, K.; Santoso, J. The potential of Eucheuma cottonii extract as a candidate for fish anesthetic agent. Aquac. Fish. 2021. [CrossRef]

86. Vimala, B.L.C.; June, I.A.B.; Fairunizal, M.N.; Syahida, A.; Ismail, I. Composition of docosahexaenoic acid, eicosapentaenoic acid and palmitoleic acid in Eucheuma denticulatum, Sargassum polycystum and Caulerpa lentillifera ethanolic extracts by LC-ESI-MS/MS. J. Mar. Biol. Oceanogr. 2018, 7, 1. [CrossRef]

87. Yum, H.W.; Na, H.K.; Surh, Y.J. Anti-inflammatory effects of docosahexaenoic acid: Implications for its cancer chemopreventive potential. Semin. Cancer Biol. 2016, 40-41, 141-159. [CrossRef] [PubMed]

88. Riediger, N.D.; Othman, R.A.; Suh, M.; Moghadasian, M.H. A systemic review of the roles of n-3 fatty acids in health and disease. J. Am. Diet. Assoc. 2009, 109, 668-679. [CrossRef] [PubMed]

89. Gumgumjee, N.; Hajar, A.S. Antibacterial activities and GC-MS analysis of phytocomponents of Ehretia abyssinica R.Br. Int. J. Appl. Biol. Phamaceutical Technol. 2015, 6, 236-242.

90. Dhevika, S.; Deivasigamani, B. Phytochemical profiling and GC-MS analysis of Caulerpa racemosa. Res. J. Life Sci. Bioinformatics, Pharm. Chem. Sci. 2018, 4, 155-165. [CrossRef]

91. Tassakka, A.C.M.A.R.; Sumule, O.; Massi, M.N.; Manggau, M.; Iskandar, I.W.; Alam, J.F.; Permana, A.D.; Liao, L.M. Potential bioactive compounds as SARS-CoV-2 inhibitors from extracts of the marine red alga Halymenia durvillei (Rhodophyta) - A computational study. Arab. J. Chem. 2021, 14, 103393. [CrossRef] [PubMed] 
92. Dahham, S.S.; Tabana, Y.M.; Iqbal, M.A.; Ahamed, M.B.K.; Ezzat, M.O.; Majid, A.S.A.; Majid, A.M.S.A. The anticancer, antioxidant and antimicrobial properties of the sesquiterpene $\beta$-caryophyllene from the essential oil of Aquilaria crassna. Molecules 2015, 20, 11808-11829. [CrossRef] [PubMed]

93. Jh, Z.; Hl, S.; Sy, C.; Zeng, L.; Wang, T. Anti-fungal activity, mechanism studies on $\alpha$-Phellandrene and Nonanal against Penicillium cyclopium. Bot. Stud. 2017, 58, 13. [CrossRef]

94. Nor Qhairul Izzreen, M.N.; Vijaya Ratnam, R. Volatile compound extraction using Solid phase micro extraction coupled with gas chromatography mass spectrometry (SPME-GCMS) in local seaweeds of Kappaphycus alvarezii, Caulerpa lentillifera and Sargassum polycystem. Int. Food Res. J. 2011, 18, 1449-1456.

95. Vanitha, V.; Vijayakumar, S.; Nilavukkarasi, M.; Punitha, V.N.; Vidhya, E.; Praseetha, P.K. Heneicosane-A novel microbicidal bioactive alkane identified from Plumbago zeylanica L. Ind. Crops Prod. 2020, 154, 112748. [CrossRef]

96. Bhuyar, P.; Rahim, M.H.; Sundararaju, S.; Maniam, G.P.; Govindan, N. Antioxidant and antibacterial activity of red seaweed; Kappaphycus alvarezii against pathogenic bacteria. Glob. J. Environ. Sci. Manag. 2020, 6, 47-58. [CrossRef]

97. Solari, A.; Uitdehaag, B.M.; Giuliani, G.; Pucci, E.; Taus, C. Aminopyridines for symptomatic treatment in multiple sclerosis. Cochrane Database Syst. Rev. 2002, 4, CD001330. [CrossRef]

98. Das, U.N. Gamma-linolenic acid, arachidonic acid, and eicosapentaenoic acid as potential anticancer drugs. Nutrition 1990, 6, 429-434. [PubMed]

99. de Souza, C.O.; Valenzuela, C.A.; Baker, E.J.; Miles, E.A.; Rosa Neto, J.C.; Calder, P.C. Palmitoleic acid has stronger antiinflammatory potential in human endothelial cells compared to Oleic and Palmitic acids. Mol. Nutr. Food Res. 2018, 62, 1800322. [CrossRef] [PubMed]

100. Balasubramaniam, V.; June Chelyn, L.; Vimala, S.; Mohd Fairulnizal, M.N.; Brownlee, I.A.; Amin, I. Carotenoid composition and antioxidant potential of Eucheuma denticulatum, Sargassum polycystum and Caulerpa lentillifera. Heliyon 2020, 6, e04654. [CrossRef]

101. Shimode, S.; Miyata, K.; Araki, M.; Shindo, K. Antioxidant activities of the Antheraxanthin-related carotenoids, Antheraxanthin, 9-cis-Antheraxanthin, and Mutatoxanthins. J. Oleo Sci. 2018, 67, 977-981. [CrossRef] [PubMed]

102. Farruggia, C.; Kim, M.B.; Bae, M.; Lee, Y.; Pham, T.X.; Yang, Y.; Han, M.J.; Park, Y.K.; Lee, J.Y. Astaxanthin exerts anti-inflammatory and antioxidant effects in macrophages in NRF2-dependent and independent manners. J. Nutr. Biochem. 2018, 62, 202-209. [CrossRef]

103. Mueller, L.; Boehm, V. Antioxidant activity of $\beta$-carotene compounds in different in vitro assays. Molecules 2011, 16, 1055-1069. [CrossRef]

104. Gansukh, E.; Nile, A.; Sivanesan, I.; Rengasamy, K.R.R.; Kim, D.H.; Keum, Y.S.; Saini, R.K. Chemopreventive effect of $\beta$ cryptoxanthin on human cervical carcinoma (HeLa) cells is modulated through oxidative stress-induced apoptosis. Antioxidants 2020, 9, 28. [CrossRef] [PubMed]

105. Lorenzo, Y.; Azqueta, A.; Luna, L.; Bonilla, F.; Domínguez, G.; Collins, A.R. The carotenoid $\beta$-cryptoxanthin stimulates the repair of DNA oxidation damage in addition to acting as an antioxidant in human cells. Carcinogenesis 2009, 30, 308-314. [CrossRef]

106. Ngginak, J.; Mangibulude, J.C.; Rondonuwu, F.S. The identification of carotenoids and testing of carotenoid antioxidants from Sand lobster (Panulirus homarus) egg extract. Indones. J. Mar. Sci./Imu Kelautan 2017, 22, 155-160. [CrossRef]

107. Pistelli, L.; Sansone, C.; Smerilli, A.; Festa, M.; Noonan, D.M.; Albini, A.; Brunet, C. Mmp-9 and il-1 $\beta$ as targets for diatoxanthin and related microalgal pigments: Potential chemopreventive and photoprotective agents. Mar. Drugs 2021, 19, 354. [CrossRef] [PubMed]

108. Satomi, Y. Fucoxanthin inhibits tumor cell growth by inducing G 1 cell-cycle arrest with/ without apoptosis in various tumor =cells antitumor and cancer-preventative function of Fucoxanthin: A marine carotenoid. Anticancer. Res. 2017, 37, 1557-1562. [CrossRef] [PubMed]

109. Mezzomo, N.; Ferreira, S.R.S. Carotenoids functionality, sources, and processing by supercritical technology: A review. J. Chem. 2016, 2016, 16. [CrossRef]

110. Hendry, E.R.; Worthington, T.; Conway, B.R.; Lambert, P.A. Antimicrobial efficacy of Eucalyptus oil and 1,8-cineole alone and in combination with chlorhexidine digluconate against microorganisms grown in planktonic and biofilm cultures. J. Antimicrob. Chemother. 2009, 64, 1219-1225. [CrossRef]

111. Juergens, U.R.; Dethlefsen, U.; Steinkamp, G.; Gillissen, A.; Repges, R.; Vetter, H. Anti-inflammatory activity of 1.8-cineol (eucalyptol) in bronchial asthma: A double-blind placebo-controlled trial. Respir. Med. 2003, 97, 250-256. [CrossRef] [PubMed]

112. Shibula, K.; Velavan, S. Determination of phytocomponents in methanolic extract of Annona muricata leaf Using GC-MS technique. Int. J. Pharmacogn. Phytochem. Res. 2015, 7, 1251-1255.

113. Singh, V.K.; Kavita, K.; Prabhakaran, R.; Jha, B. Cis-9-octadecenoic acid from the rhizospheric bacterium Stenotrophomonas maltophilia BJ01 shows quorum quenching and anti-biofilm activities. Biofouling 2013, 29, 855-867. [CrossRef] [PubMed]

114. Chanprapai, P.; Kubo, I.; Chavasiri, W. Anti-rice pathogenic microbial activity of Persicaria sp. extracts. Sci. Technol. Asia 2018, 23, 32-41. [CrossRef]

115. Xu, C.; Wu, P.; Gao, J.; Zhang, L.; Ma, T.; Ma, B.; Yang, S.; Shao, G.; Yu, Y.; Huang, X.; et al. Heptadecanoic acid inhibits cell proliferation in PC-9 non-small-cell lung cancer cells with acquired gefitinib resistance. Oncol. Rep. 2019, 41, 3499-3507. [CrossRef] [PubMed]

116. To, N.B.; Nguyen, Y.T.K.; Moon, J.Y.; Ediriweera, M.K.; Cho, S.K. Pentadecanoic acid, an odd-chain fatty acid, suppresses the stemness of MCF-7/SC human breast cancer stem-like cells through JAK2/STAT3 signaling. Nutrients 2020, 12, 1663. [CrossRef] 
117. Sivakumar, R.; Jebanesan, A.; Govindarajan, M.; Rajasekar, P. Larvicidal and repellent activity of tetradecanoic acid against Aedes aegypti (Linn.) and Culex quinquefasciatus (Say.) (Diptera: Culicidae). Asian Pac. J. Trop. Med. 2011, 4, 706-710. [CrossRef]

118. Chan, K.C.; Mong, M.C.; Yin, M.C. Antioxidative and anti-inflammatory neuroprotective effects of Astaxanthin and Canthaxanthin in nerve growth factor differentiated PC12 cells. J. Food Sci. 2009, 74, H225-H231. [CrossRef]

119. Halim, N.A.; Zamimi, N.N.; Kamar, S.H.S. Analysis of the fatty acid composition of Caulerpa Lentillifera using gas chromatography mass spectrometry. Int. J. Allied Health Sci. 2019, 3, 806.

120. Bhattacharjee, B.; Pal, P.K.; Chattopadhyay, A.; Bandyopadhyay, D. Oleic acid protects against Cadmium induced cardiac and hepatic tissue injury in male Wistar rats: A mechanistic study. Life Sci. 2020, 244, 117324. [CrossRef] [PubMed]

121. Khalil, A.S.M.; Giribabu, N.; Yelumalai, S.; Shahzad, H.; Kilari, E.K.; Salleh, N. Myristic acid defends against testicular oxidative stress, inflammation, apoptosis: Restoration of spermatogenesis, steroidogenesis in diabetic rats. Life Sci. 2021, $278,119605$. [CrossRef]

122. Moreira, D.K.T.; Santos, P.S.; Gambero, A.; Macedo, G.A. Evaluation of structured lipids with behenic acid in the prevention of obesity. Food Res. Int. 2017, 95, 52-58. [CrossRef]

123. Harada, H.; Yamashita, U.; Kurihara, H.; Fukushi, E.; Kawabata, J.; Kamei, Y. Antitumor activity of palmitic acid found as a selective cytotoxic substance in a marine red alga. Anticancer Res. 2002, 22, 2587-2590.

124. Arruda, D.C.; Miguel, D.C.; Yokoyama-Yasunaka, J.K.U.; Katzin, A.M.; Uliana, S.R.B. Inhibitory activity of limonene against Leishmania parasites in vitro and in vivo. Biomed. Pharmacother. 2009, 63, 643-649. [CrossRef]

125. Okechukwu, P.N. Evaluation of anti-Inflammatory, analgesic, antipyretic effect of Eicosane, Pentadecane, Octacosane, and Heneicosane. Asian J. Pharm. Clin. Res. 2020, 13, 29-35. [CrossRef]

126. Guarrera, M.; Turbino, L.; Rebora, A. The anti-inflammatory activity of Azulene. J. Eur. Acad. Dermatol. Venereol. 2001, 15, 486-487. [CrossRef]

127. Wu, Z.; Kong, X.; Zhang, T.; Ye, J.; Fang, Z.; Yang, X. Pseudoephedrine/ephedrine shows potent anti-inflammatory activity against TNF- $\alpha$-mediated acute liver failure induced by lipopolysaccharide/d-galactosamine. Eur. J. Pharmacol. 2014, 724, 112-121. [CrossRef]

128. Lee, J.I.; Burckart, G.J. Nuclear factor kappa B: Important transcription factor and therapeutic target. J. Clin. Pharmacol. 1998, 38, 981-993. [CrossRef]

129. Aissaoui, N.; Mahjoubi, M.; Nas, F.; Mghirbi, O.; Arab, M.; Souissi, Y.; Hoceini, A.; Masmoudi, A.S.; Mosbah, A.; Cherif, A.; et al. Antibacterial potential of 2,4-Di-tert-Butylphenol and Calixarene-based prodrugs from Thermophilic Bacillus licheniformis isolated in Algerian hot spring. Geomicrobiol. J. 2019, 36, 53-62. [CrossRef]

130. Nair, R.V.R.; Jayasree, D.V.; Biju, P.G.; Baby, S. Anti-inflammatory and anticancer activities of Erythrodiol-3-acetate and 2,4-Di-tertbutylphenol isolated from Humboldtia unijuga. Nat. Prod. Res. 2020, 34, 2319-2322. [CrossRef]

131. Dandekar, R.; Fegade, B.; Vh, B. GC-MS analysis of phytoconstituents in alcohol extract of Epiphyllum oxypetalum leaves. J. Pharmacogn. Phytochem. Mater. 2015, 4, 149-154.

132. Aparna, V.; Dileep, K.V.; Mandal, P.K.; Karthe, P.; Sadasivan, C.; Haridas, M. Anti-inflammatory property of n-Hexadecanoic acid: Structural evidence and kinetic assessment. Chem. Biol. Drug Des. 2012, 80, 434-439. [CrossRef] [PubMed]

133. Silva, S.D.F.; Blank, D.E.; Peixoto, C.R.; De Jesus Da Silveira Moreira, J.; Fernandes De Moura, N. Bioactive compounds and antioxidant activity of Bunchosia glandulifera. Int. J. Food Prop. 2016, 19, 467-473. [CrossRef]

134. Fernando, I.P.S.; Sanjeewa, K.K.A.; Samarakoon, K.W.; Lee, W.W.; Kim, H.S.; Jeon, Y.J. Squalene isolated from marine macroalgae Caulerpa racemosa and its potent antioxidant and anti-inflammatory activities. J. Food Biochem. 2018, 42, e12628. [CrossRef]

135. Murakoshi, M.; Nishino, H.; Tokuda, H.; Iwashima, A.; Okuzumi, J.; Kitano, H.; Iwasaki, R. Inhibition by squalene of the tumor-promoting activity of 12-O-Tetradecanoylphorbol-13-acetate in mouse-skin carcinogenesis. Int. J. Cancer 1992, 52, 950-952. [CrossRef] [PubMed]

136. Tanna, B.; Choudhary, B.; Mishra, A. Metabolite profiling, antioxidant, scavenging and anti-proliferative activities of selected tropical green seaweeds reveal the nutraceutical potential of Caulerpa spp. Algal Res. 2018, 36, 96-105. [CrossRef]

137. Parajuli, K.R.; Zhang, Q.; Liu, S.; You, Z. Aminomethylphosphonic acid and methoxyacetic acid induce apoptosis in prostate cancer cells. Int. J. Mol. Sci. 2015, 16, 11750-11765. [CrossRef] [PubMed]

138. Formuso, C.; Stracquadanio, M.; Ciotta, L. Myo-inositol vs. D-chiro inositol in PCOS treatment. Minerva Ginecol. 2015, 67, 321-325.

139. Thorgeirsdóttir, T.Ó.; Kristmundsdóttir, T.; Thormar, H.; Axelsdóttir, Í.; Holbrook, W.P. Antimicrobial activity of monocaprin: A monoglyceride with potential use as a denture disinfectant. Acta Odontol. Scand. 2006, 64, 21-26. [CrossRef] [PubMed]

140. Chukwuma, C.I.; Matsabisa, M.G.; Erukainure, O.L.; Ibeji, C.U.; Islam, M.S. D-mannitol modulates glucose uptake ex vivo; suppresses intestinal glucose absorption in normal and type 2 diabetic rats. Food Biosci. 2019, 29, 30-36. [CrossRef]

141. Kolesnikova, S.A.; Lyakhova, E.G.; Kalinovsky, A.I.; Dmitrenok, P.S.; Dyshlovoy, S.A.; Stonik, V.A. Diterpenoid hydroperoxides from the far-eastern brown alga Dictyota dichotoma. Aust. J. Chem. 2009, 62, 1185. [CrossRef]

142. Bruno, F.; Castelli, G.; Migliazzo, A.; Piazza, M.; Galante, A.; Verde, V.L.; Calderone, S.; Nucatolo, G.; Vitale, F. Cytotoxic screening and in vitro evaluation of pentadecane against leishmania infantum promastigotes and amastigotes. J. Parasitol. 2015, 101, 701-705. [CrossRef] [PubMed]

143. Abdul, Q.A.; Choi, R.J.; Jung, H.A.; Choi, J.S. Health benefit of Fucosterol from marine algae: A review. J. Sci. Food Agric. 2016, 96, 1856-1866. [CrossRef] 
144. Lee, J.A.; Cho, Y.R.; Hong, S.S.; Ahn, E.K. Anti-Obesity Activity of Saringosterol isolated from Sargassum muticum (Yendo) Fensholt Extract in 3T3-L1 Cells. Phyther. Res. 2017, 31, 1694-1701. [CrossRef]

145. Yu, F.; Lu, S.; Yu, F.; Shi, J.; McGuire, P.M.; Wang, R. Cytotoxic activity of an octadecenoic acid extract from Euphorbia kansui (Euphorbiaceae) on human tumour cell strains. J. Pharm. Pharmacol. 2010, 60, 253-259. [CrossRef]

146. Bhardwaj, M.; Sali, V.K.; Mani, S.; Vasanthi, H.R. Neophytadiene from Turbinaria ornata suppresses LPS-induced inflammatory response in RAW 264.7 Macrophages and Sprague Dawley rats. Inflammation 2020, 43, 937-950. [CrossRef]

147. Nazarudin, M.F.; Alias, N.H.; Balakrishnan, S.; Wan Hasnan, W.N.I.; Noor Mazli, N.A.I.; Ahmad, M.I.; Md Yasin, I.S.; Isha, A.; Aliyu-Paiko, M. Chemical, nutrient and physicochemical properties of brown seaweed, Sargassum polycystum c. Agardh (phaeophyceae) collected from port dickson, Peninsular Malaysia. Molecules 2021, 26, 5216. [CrossRef] [PubMed]

148. Hirotani, H.; Ohigashi, H.; Kobayashi, M.; Koshimizu, K.; Takahashi, E. Inactivation of T5 phage by cis-vaccenic acid, an antivirus substance from Rhodopseudomonas capsulata, and by unsaturated fatty acids and related alcohols. FEMS Microbiol. Lett. 1991, 77, 13-18. [CrossRef]

149. Xiao, W.H.; Zheng, F.Y.; Bennett, G.J.; Bordet, T.; Pruss, R.M. Olesoxime (cholest-4-en-3-one, oxime): Analgesic and neuroprotective effects in a rat model of painful peripheral neuropathy produced by the chemotherapeutic agent, paclitaxel. Pain 2009, 147, 202-209. [CrossRef] [PubMed] 